\title{
Correction of Monogenic and Common Retinal Disorders with Gene Therapy
}

\author{
Jesse D. Sengillo ${ }^{1,2,3,+}$, Sally Justus ${ }^{1,2, \dagger}{ }^{\dagger}$, Thiago Cabral ${ }^{1,2,4,5}$ and Stephen H. Tsang ${ }^{1,2,6, *}$ \\ 1 Jonas Children's Vision Care, and Bernard \& Shirlee Brown Glaucoma Laboratory, \\ Department of Ophthalmology, Columbia University Medical Center, New York, NY 10032, USA; \\ js3899@cumc.columbia.edu (J.D.S.); sj2750@cumc.columbia.edu (S.J.); tc2803@cumc.columbia.edu (T.C.) \\ 2 Edward S. Harkness Eye Institute, New York-Presbyterian Hospital, New York, NY 10032, USA \\ 3 State University of New York Downstate Medical Center, Brooklyn, NY 11203, USA \\ 4 Department of Ophthalmology, Federal University of Espírito Santo, Vitória 29075-910, Brazil \\ 5 Department of Ophthalmology, Federal University of São Paulo, São Paulo 04021-001, Brazil \\ 6 Department of Pathology \& Cell Biology, Institute of Human Nutrition, College of Physicians and Surgeons, \\ Columbia University, New York, NY 10032, USA \\ * Correspondence: sht2@columbia.edu; Tel.: +1-212-342-1189; Fax: +1-212-305-4987 \\ $\dagger$ These authors contributed equally to this work.
}

Academic Editor: Selvarangan Ponnazhagan

Received: 1 November 2016; Accepted: 19 January 2017; Published: 27 January 2017

\begin{abstract}
The past decade has seen major advances in gene-based therapies, many of which show promise for translation to human disease. At the forefront of research in this field is ocular disease, as the eye lends itself to gene-based interventions due to its accessibility, relatively immune-privileged status, and ability to be non-invasively monitored. A landmark study in 2001 demonstrating successful gene therapy in a large-animal model for Leber congenital amaurosis set the stage for translation of these strategies from the bench to the bedside. Multiple clinical trials have since initiated for various retinal diseases, and further improvements in gene therapy techniques have engendered optimism for alleviating inherited blinding disorders. This article provides an overview of gene-based strategies for retinal disease, current clinical trials that engage these strategies, and the latest techniques in genome engineering, which could serve as the next frontline of therapeutic interventions.
\end{abstract}

Keywords: gene therapy; genome engineering; CRISPR; retinal degeneration; inherited retinal disease

\section{Introduction}

Gene therapy holds the potential to revolutionize physicians' ability to apply precision medicine. Depending on the inheritance pattern of a given genetic defect, gene therapy may involve the delivery of genetic material that either silences a pathogenic mutation or supplements patients with a wild type copy of a mutated gene. Enthusiasm for such strategies grew quickly, until the death of a clinical trial patient following a gene therapy-based intervention for ornithine transcarbamylase (OTC) deficiency [1], in addition to other adverse outcomes following gene therapy [2], prompted careful reevaluation of the ethical and safety considerations involved with such strategies. Vector choice and delivery strategies came under close scrutiny, and additional testing in animal models was emphasized as an essential pre-clinical safety measure.

In 1996, a team that included Drs. Bennett, Maguire and Gouras presented the first study to use gene transfer to rescue retinal degeneration in a mouse model of retinitis pigmentosa (RP) [3]. Subretinal injection of a recombinant adenovirus carrying wild type cDNA of the phosphodiesterase $\beta$ 
subunit ( $\beta P D E$ ) effectively delayed photoreceptor degeneration in the $r d$ mouse model, which harbors biallelic mutations in the $\beta$ subunit of rod cGMP-phosphodiesterase. Later, in 2001, injection of an adeno-associated virus (AAV) delivering subretinal RPE65 to an RPE65-/- canine model was reported to delay disease progression and even restore visual function [4]. These studies provided an initial preclinical proof-of-principle for such strategies to be translated to clinical trials. Multiple groups subsequently launched clinical trials to deliver subretinal RPE65 via an AAV vector to patients with Leber congenital amaurosis [5-7], reinvigorating research in gene therapy.

The eye has been at the forefront of developments in gene-based technology because it possesses several unique anatomical and physiological properties. The eye and retina are easily accessible to physicians, and in clinical trials, the untreated eye can serve as a control if the condition progresses symmetrically [8,9]. The optical transparency of the eye allows in vivo, longitudinal, and non-invasive monitoring of disease progression and treatment response [10]. Moreover, the retina can be viewed with impressively high resolution, on the scale of microns, with spectral domain optical coherence tomography (SD-OCT), enabling visualization and delineation of the individual layers of the retina [10,11]. Retinal imaging continues to improve, and OCT imaging can now be acquired en face, with images oriented parallel to the plane of the retina as opposed to perpendicular, as in the traditional SD-OCT system [11-16]. These improvements can lead to an even deeper understanding of previously well-characterized diseases and open new doors for less-studied conditions. OCT, as well as other imaging modalities such as fundus autofluorescence, have allowed investigators to characterize retinal disease and identify potential outcome measures for disease progression and treatment efficacy, supplementing traditional tests of visual function [10,17-27]. Another factor that makes the eye more approachable to gene therapy is its relatively immune-privileged status. This is maintained by a lack of lymphatics, immunomodulatory factors in the vitreous humor, and antigen-presenting cells, hence leading to a significantly weaker immune response to novel antigens [28].

The advantages the eye confers for studying gene-based therapies has accelerated research initiatives in this area, and today, there are multiple clinical trials utilizing such strategies in the treatment of retinal disease (Table 1). This article will review some of the parameters that must be considered for gene delivery in the eye, provide examples of applications of these techniques in current clinical trials, and present an overview of some of the latest advances in genome surgery and their future applications to treating inherited retinal dystrophies.

Table 1. Gene therapy trials for retinal diseases, with relevant articles cited.

\begin{tabular}{|c|c|c|c|c|}
\hline Disease & NCT ID \& Sponsor & Phase & Intervention & Citations \\
\hline \multirow{5}{*}{$\begin{array}{l}\text { Leber Congenital } \\
\text { Amaurosis }\end{array}$} & $\begin{array}{l}\text { NCT00999609 } \\
\text { NCT01208389 } \\
\text { NCT00516477 } \\
\text { Spark Therapeutics } \\
\text { (Philadelphia, PA, USA) }\end{array}$ & $\begin{array}{l}\text { III } \\
\text { I, II } \\
\text { I }\end{array}$ & $\begin{array}{l}\text { Subretinal } \\
\text { AAV2-hRPE65v2 }\end{array}$ & {$[7,29-33]$} \\
\hline & $\begin{array}{l}\text { NCT00643747 } \\
\text { University College, London } \\
\text { (London, UK) }\end{array}$ & I, II & $\begin{array}{l}\text { Subretinal } \\
\text { rAAV2/2.hRPE65p.hRPE65 } \\
\text { (tgAAG76) }\end{array}$ & {$[5,34-36]$} \\
\hline & $\begin{array}{l}\text { NCT00749957 } \\
\text { Applied Genetic Technologies Corp. } \\
\text { (Alachua, FL, USA) }\end{array}$ & I, II & $\begin{array}{l}\text { Subretinal } \\
\text { rAAV2-CB-hRPE65 }\end{array}$ & [37] \\
\hline & $\begin{array}{l}\text { NCT01496040 } \\
\text { Nantes University Hospital } \\
\text { (Nantes, France) }\end{array}$ & I, II & $\begin{array}{l}\text { Subretinal } \\
\text { rAAV2/4.hRPE65 }\end{array}$ & \\
\hline & $\begin{array}{l}\text { NCT00481546 } \\
\text { University of Pennsylvania } \\
\text { (Philadelphia, PA, USA) }\end{array}$ & I & $\begin{array}{l}\text { Subretinal } \\
\text { rAAV2-CBSB-hRPE65 }\end{array}$ & [39-42] \\
\hline
\end{tabular}


Table 1. Cont.

\begin{tabular}{|c|c|c|c|c|}
\hline Disease & NCT ID \& Sponsor & Phase & Intervention & Citations \\
\hline \multirow{4}{*}{ Choroideremia } & $\begin{array}{l}\text { NCT02077361 } \\
\text { Ian M. MacDonald }\end{array}$ & I, II & $\begin{array}{l}\text { Subretinal } \\
\text { rAAV2.REP1 }\end{array}$ & \\
\hline & $\begin{array}{l}\text { NCT02553135 } \\
\text { Byron Lam }\end{array}$ & II & $\begin{array}{l}\text { Subretinal } \\
\text { AAV2-REP1 }\end{array}$ & \\
\hline & $\begin{array}{l}\text { NCT01461213 } \\
\text { NightstaRx } \\
\text { (London, UK) }\end{array}$ & I, II & $\begin{array}{l}\text { Subretinal } \\
\text { AAV2.REP1 }\end{array}$ & [43-45] \\
\hline & $\begin{array}{l}\text { NCT02341807 } \\
\text { Spark Therapeutics } \\
\text { (Philadelphia, PA, USA) }\end{array}$ & I, II & $\begin{array}{l}\text { Subretinal } \\
\text { AAV2-hCHM }\end{array}$ & \\
\hline Achromatopsia & $\begin{array}{l}\text { NCT02610582 } \\
\text { STZ eyetrial } \\
\text { (Tübingen, Germany) }\end{array}$ & I, II & $\begin{array}{l}\text { Subretinal } \\
\text { rAAV.hCNGA3 }\end{array}$ & \\
\hline \multirow{2}{*}{ X-linked Retinoschisis } & $\begin{array}{l}\text { NCT02317887 } \\
\text { National Eye Institute } \\
\text { (Bethesda, MD, USA) }\end{array}$ & I, II & $\begin{array}{l}\text { Intravitreal } \\
\text { AAV8-scRS/IRBPhRS }\end{array}$ & [49-52] \\
\hline & $\begin{array}{l}\text { NCT02416622 } \\
\text { Applied Genetic Technologies Corp. } \\
\text { (Alachua, FL, USA) }\end{array}$ & I, II & $\begin{array}{l}\text { Intravitreal } \\
\text { rAAV2tYF-CB-hRS1 }\end{array}$ & {$[53,54]$} \\
\hline $\begin{array}{l}\text { Leber Hereditary } \\
\text { Optic Neuropathy }\end{array}$ & $\begin{array}{l}\text { NCT02652767 } \\
\text { NCT02652780 } \\
\text { GenSight Biologics } \\
\text { (Paris, France) }\end{array}$ & $\begin{array}{l}\text { III } \\
\text { III }\end{array}$ & $\begin{array}{l}\text { Intravitreal GS010; Sham } \\
\text { intravitreal injection }\end{array}$ & {$[55]$} \\
\hline \multirow[t]{2}{*}{ Retinitis Pigmentosa } & $\begin{array}{l}\text { NCT02556736 } \\
\text { Retrosense Therapeutics } \\
\text { (Ann Arbor, MI, USA) }\end{array}$ & I, II & $\begin{array}{l}\text { Intravitreal } \\
\text { RST-001 }\end{array}$ & {$[60,61]$} \\
\hline & $\begin{array}{l}\text { NCT01482195 } \\
\text { Fowzan Alkuraya }\end{array}$ & I & $\begin{array}{l}\text { Subretinal } \\
\text { rAAV2-VMD2-hMERTK }\end{array}$ & {$[62,63]$} \\
\hline Usher Syndrome & $\begin{array}{l}\text { NCT01505062 } \\
\text { NCT02065011 } \\
\text { Sanofi } \\
\text { (Paris, France) }\end{array}$ & $\begin{array}{l}\text { I, II } \\
\text { I, II }\end{array}$ & $\begin{array}{l}\text { Subretinal } \\
\text { EIAV-CMV-MYO7A } \\
\text { (UshStat) }\end{array}$ & {$[64]$} \\
\hline Stargardt Disease & $\begin{array}{l}\text { NCT01736592 } \\
\text { NCT01367444 } \\
\text { Sanofi } \\
\text { (Paris, France) } \\
\end{array}$ & $\begin{array}{l}\text { I, II } \\
\text { I, II }\end{array}$ & $\begin{array}{l}\text { Subretinal } \\
\text { SAR422459 }\end{array}$ & [65-67] \\
\hline \multirow{3}{*}{$\begin{array}{l}\text { Neovascular Age-Related } \\
\text { Macular Degeneration }\end{array}$} & $\begin{array}{l}\text { NCT01494805 } \\
\text { Lions Eye Institute } \\
\text { (Perth, WA, Australia) }\end{array}$ & I, II & $\begin{array}{l}\text { Subretinal rAAV.sFlt-1; } \\
\text { Control (ranibizumab alone) }\end{array}$ & [68-70] \\
\hline & $\begin{array}{l}\text { NCT01024998 } \\
\text { Genzyme, a Sanofi company } \\
\text { (Cambridge, MA, USA) }\end{array}$ & I & Intravitreal AAV2-sFLT01 & [71-73] \\
\hline & $\begin{array}{l}\text { NCT01301443 } \\
\text { NCT01678872 } \\
\text { Oxford BioMedica } \\
\text { (Oxford, UK) }\end{array}$ & $\begin{array}{l}\text { I } \\
\text { I }\end{array}$ & Subretinal RetinoStat & [73-75] \\
\hline
\end{tabular}

\section{Vector Choice}

While there exist a variety of techniques for delivering genes into target cells, the most popular options for use in patients include viral-mediated strategies typically involving one of two viruses: AAVs or lentiviruses. AAV, a single-stranded DNA vector belonging to the family Parvoviridae, 
remains the vector of choice for most ocular gene therapy applications due to several advantageous properties: AAVs elicit less immunogenic reactions than that observed from administration of adenoviral vectors; they exhibit minimal self-replication; and they can last for up to six years after a single administration [76,77]. Furthermore, a recombinant AAV (rAAV) capsid can be selected or altered to suit different experimental needs and to optimize transfection [78-80]. While each of these characteristics are advantageous for gene-based therapy, some challenges remain.

A known limitation of AAVs is their carrying capacity, which is approximately $4.5 \mathrm{~kb}$, making gene-based delivery difficult for longer genes [81]. Researchers studying delivery of genes larger than $5 \mathrm{~kb}$ have circumvented this issue by utilizing dual AAV strategies. Yan et al. were the first to employ a dual AAV strategy, effectively delivering the erythropoietin genomic locus to mouse muscle tissue [82]. A similar study reported that this dual AAV technique could be applied to the retina [83], and subsequent studies successfully delivered the MYO7A gene in vitro and in vivo. Encouragingly, co-infected cells showed recombination of the two halves, leading to a full-length gene product $[84,85]$. Another strategy for delivering large genes is with lentiviral vectors. Lentiviruses are retroviruses that can carry up to $8 \mathrm{~kb}$ of transgene material [86]. Large genes such as MYO7A (Usher syndrome) and $A B C A 4$ (Stargardt disease) have been approached successfully with lentiviruses in pre-clinical studies [64,67] and are currently being tested in clinical trials (Table 1).

\section{Vector Delivery}

\subsection{Subretinal Injection}

Most gene therapy trials for retinal degenerations involve subretinal injection of the vector-containing therapeutic (Table 1). To accomplish this, a transient retinal detachment is made intraoperatively to create a subretinal space to place the injection. This detachment resolves spontaneously [9]. The viral vector subsequently occupies the subretinal space and infects target cells of the neurosensory retina or retinal pigment epithelium (RPE). Subretinal injections are particularly localized, which has been postulated to affect transfection and may explain the variable patterns of functional vision improvement that were observed in the clinical trials of Leber congenital amaurosis (LCA) [41,87]. For example, portions of the detachment that reattach first (such as the edges) may have lower transfection $[41,87,88]$. Although there is no proven superior alternative to subretinal injection for most retinal degenerations at this time, patients may benefit from more homogeneously distributed and less invasive strategies [87].

\subsection{Intravitreal Injection}

The intravitreal AAV2 virus that is currently used predominantly infects the ganglion cell layer that lies close to the vitreous cavity $[89,90]$. This is in comparison to subretinal injections, in which cells in the area of the induced bleb, such as photoreceptors and RPE, are transduced [91]. For therapies targeting the inner retina, such as in Leber hereditary optic neuropathy (LHON), the intravitreal route of administration may prove successful in clinical trials (Table 1). The intravitreal approach is also less invasive, thus potentially decreasing the chance for complications [92]. This may be advantageous for retinas that are particularly at risk for retinal detachment, such as in X-linked retinoschisis (XLRS), which is caused by mutations in retinoschisin 1 (RS1) [93]. Furthermore, RS1 protein is normally secreted and may impart its effects on areas that are more distant to that which is transduced by a subretinal injection [93,94]. Although the eye is considered to be immune-privileged, previous experiments in mice suggest that the vitreous compartment may respond differently to AAV2 compared to the subretinal space $[95,96]$. Li et al. found that intravitreal injection of AAV2-CBA-PEDF resulted in a humoral immune response which prevented therapeutic effects upon readministration in a mouse model for choroidal neovascularization [96]. The same effect was not observed via subretinal administration. In LHON and XLRS pre-clinical studies, however, favorable safety and biodistribution were reported for single injections of AAV-containing gene therapy administered to the vitreous, 
corroborating findings in phase I trials for LHON that report no inflammatory response of the vitreous or anterior chamber (Table 1) [54,56-58]. Biodistribution of gene-based therapeutics delivered to the vitreous remains complex, but pre-clinical and phase 1 clinical trial results are encouraging.

\subsection{Non-Viral Strategies}

To date, non-viral gene delivery strategies have not been used in human retina, but they deserve mention due to their success and continued improvements in animal models. Electroporation is a strategy developed by Matsuda and Cepko [97] in which DNA is directly injected in the subretinal space without being packaged into a vector. A non-invasive, high voltage pulse is subsequently administered, leading to changes in membrane potential and permeability, and thus cellular uptake of the nucleic acid [98]. This method is especially useful for quickly testing promoter activity and the effect of protein overexpression in models of retinal degeneration [97]. Previously thought to have little therapeutic potential in humans, electroporation has advanced significantly, particularly through suprachoroidal injection of DNA followed by ab externo electroporation, which is less invasive and results in a large area of transfection [99].

Nanoparticles (NPs) have also been studied for the purpose of gene therapy delivery, mainly through polymers, liposomes, and peptide-compacted DNA, which has been extensively reviewed elsewhere $[100,101]$. Compared to AAV technology, NPs may be more cost-effective but have lower transfection efficiency [102,103]. Additional advantages of NPs over AAVs include a carrying capacity up to $20 \mathrm{kbp}$ and a lower likelihood of complications, as there is less potential for insertional mutagenesis. This technology, like electroporation, has not been translated to clinical trials but has shown progress as an approach to ocular gene therapy [104-112].

\section{Update on Gene Therapy Trials for Retinal Disease}

\subsection{Leber Congenital Amaurosis}

LCA causes a severe early-onset retinal dystrophy with an estimated prevalence of 2-3 per 100,000 births [113]. As previously stated, gene therapy trials for RPE65-associated LCA are arguably among the major accomplishments in modern medicine (Table 1). RPE65 is a protein required for recycling visual pigment in the retinal pigment epithelium [114]. Mutations in RPE65 are one cause of LCA, which typically manifests as severe visual dysfunction at birth with a pigmented retina, wandering nystagmus, and amaurotic pupils [115]. After efficacy was shown in a naturally occurring canine model, multiple clinical trials confirmed that an AAV vector delivering RPE65 was safe and improved visual function during the follow-up of LCA patients $[4-7,29,31-33,40,116-119]$. Spark Therapeutics (Philadelphia, PA, USA) is sponsoring a phase III trial for bilateral subretinal delivery of AAV containing RPE65. In an October 2015 press release, Spark stated the trial met its primary endpoint of improved bilateral mobility test change score and two secondary endpoints, which included favorable full-field light sensitivity and mobility test change scores for the first treated eye compared to baseline. Visual acuity was a secondary outcome measure, but it was not met.

\subsection{Choroideremia}

Approximately 1 in 50,000 individuals are affected by choroideremia (CHM), an X-linked retinal dystrophy [120]. Affected males typically present with night blindness and a progressively constricting visual field, similar to retinitis pigmentosa [121]. A mutation in CHM, which expresses REP-1, leads to chorioretinal degeneration starting in the mid-periphery. A pale fundus is observed as the sclera illuminates through the degenerated layers of RPE and choriocapillaries. Female carriers may exhibit changes on electroretinography despite no visual complaints [120,122]. Multiple phase I/II studies to test the efficacy of rAAV-REP1 delivery are ongoing (Table 1). Initial findings reported by MacLaren et al. [43] suggested improved visual function in two of six patients, even in the context of iatrogenic retinal detachment that is required intraoperatively (NCT01461213). Increased sensitivity 
measured via microperimetry in the treated eyes correlated with vector dose per area of live retina. A follow-up study showed sustained improvement in visual acuity of the same two patients after 3.5 years, while the control eyes continued to progress [123]. Choroideremia patients possibly have less surgical risk when treated earlier, as one treated patient had intraoperative complications from extensive retinal detachment. Hence, treatment may be more appropriate when there is less cell loss and a more intact retinal structure [124].

\subsection{Achromatopsia}

Patients with achromatopsia, also known as rod monochromatism, typically experience decreased visual acuity, nystagmus, photophobia, decreased color vision, and a central visual field defect. The condition is estimated to affect 1 in 30,000 individuals $[125,126]$. On OCT, an optical gap can be seen, representing foveal hypoplasia [126]. This condition is inherited recessively, and multiple genes of the phototransduction pathway have been implicated. Most commonly, the cyclic nucleotide-gated ion channel B3 gene (CNGB3) is mutated in patients of European descent [127]. CNGB3 encodes a subunit of the CNG channel, which closes in the presence of a light stimulus, hyperpolarizing the photoreceptor [128]. Applied Genetic Technologies Corporation (AGTC) (Alachua, FL, USA) is sponsoring a phase I/II trial delivering rAAV2tYF-PR1.7-hCNGB3 to achromatopsia patients (Table 1). Additionally, another phase I/II gene therapy clinical trial has launched in Tübingen, Germany for patients with achromatopsia caused by defects in a similar gene, CNGA3 (Table 1).

\subsection{X-Linked Retinoschisis}

XLRS is a common cause of macular degeneration in young males and is estimated to affect between 1 in 5000 and 1 in 25,000 individuals [129]. Characteristic symptoms include central vision loss and mildly decreased visual acuity due to foveomacular schisis. A spoke-wheel appearance encompassing the fovea is seen on fundoscopy, and OCT reveals cysts throughout the macula, including the fovea [130]. Two phase I/II clinical trials sponsored by the National Eye Institute (NEI) and AGTC are ongoing (Table 1). Each trial is testing therapeutic delivery of the causative gene, $R S 1$, utilizing a different vector and promoter. Both trials are delivering the vector via an intravitreal injection, which is likely more ideal, as the retina in XLRS patients is fragile, and the foveomacular schisis does not provide ideal anatomy for subretinal injection [94]. Retina specialists should carefully assess XLRS patients for enrollment in clinical trials, as patients' visual function may not be sufficiently reduced to meet inclusion criteria.

\subsection{Leber Hereditary Optic Neuropathy}

LHON is an inherited mitochondrial disease that causes degeneration of the retinal ganglion cells and is thus characterized by optic atrophy. The prevalence is estimated to be approximately 1 in 31,000 to 50,000 among Northern European populations, and the three most common genetic causes are mutations in ND1, ND4, or ND6, which code for a key enzyme in cellular respiration in mitochondria [131]. Current vectors of gene therapy cannot faithfully deliver therapeutic genes directly into the mitochondria. Researchers overcame this challenge by demonstrating that allotopically expressed ND4 delivered into the vitreous via an AAV vector was effective in a mouse model of LHON [132-134]. This strategy has subsequently been translated to a clinical trial sponsored by GenSight Biologics (Paris, France). Initial results from the open-label phase I study reported no outstanding adverse events following administration of GS010, an AAV vector carrying normal ND4, in patients with ND4-associated LHON. At the 90-day follow-up appointment, two patients had an increase in visual acuity, and three patients were unchanged from baseline [58]. In the phase III study, which is currently recruiting subjects, the effects of intravitreal GS010 injection will be compared to a sham-control. 


\subsection{Retinitis Pigmentosa}

$\mathrm{RP}$ is a genetically heterogenous disease with nearly 80 genes associated with the condition, which can be inherited in multiple fashions, namely dominantly, recessively, or in X-linked or mitochondrial forms [135]. Affecting approximately 1 in 4000 individuals, RP presents at various ages with night blindness as a first symptom. Degeneration typically starts at the mid-periphery and progresses towards the macula, corresponding to a constricting visual field [136]. Homozygous or compound heterozygous mutations in the mer receptor tyrosine kinase (MERTK) gene are a rare cause of autosomal recessive RP, which is being approached with gene therapy at the King Khaled Eye Specialist Hospital and King Faisal Specialist Hospital \& Research Center (Riyadh, Saudi Arabia). Results of a phase I trial administering rAAV2-VMD2-hMERTK to one eye in each of six patients with MERTK-associated RP were recently reported [62]. Safety of the vector was confirmed, and three patients experienced a post-surgical increase in visual acuity; however, this was transient in two of the patients, whose improvements returned to baseline by the two-year follow-up appointment. Another trial for clinically-diagnosed RP patients (mutation- and gene-independent) is assessing the efficacy of RST-001, an intravitreally administered gene therapy that expresses a photoswitch, channelrhodopsin-2, which allows transfected cells of the inner retina to respond to light even after photoreceptors have degenerated (Table 1). Proof-of-principle studies in mice and marmosets supported the initiation of a phase I/II clinical trial sponsored by Retrosense Therapeutics (Ann Arbor, MI, USA) [60,61].

\subsection{Usher Syndrome}

Syndromic retinitis pigmentosa associated with neurosensory hearing loss, Usher syndrome (USH), occurs with a prevalence of approximately 3-6 per 100,000 individuals, although this may be an underestimate $[137,138]$. In the absence of genetic testing, Usher syndrome can be diagnosed clinically if irreversible hearing loss occurs in the setting of retinitis pigmentosa and a family history that suggests an autosomal recessive inheritance pattern. Usher syndrome type 1 (USH1) is characterized by profound hearing loss at birth, early-onset retinitis pigmentosa, and possibly decreased vestibular function. Mutations in myosin 7a (MYO7A) can cause USH1 and are currently being studied in gene therapy clinical trials. Normally, MYO7A is involved in protein and organelle transport across photoreceptor cilia [139]. Because MYO7A is large and difficult to package in AAV, the drug UshStat ${ }^{\circledR}$ was developed by Sanofi (Paris, France) to deliver the therapeutic gene in a lentivirus vector [64]. Phase II of this trial is projected to finish in 2018.

\subsection{Stargardt Disease}

Affecting approximately 1 in 10,000 individuals, Stargardt disease is an inherited macular degeneration associated with dysfunction in the ATP-binding cassette, subfamily $\mathrm{A}$, member $4(A B C A 4)$ gene [140]. Bi-allelic pathogenic mutation of $A B C A 4$ causes accumulation of toxic byproducts in the RPE, which subsequently leads to cell degeneration [140]. Sanofi is studying the efficacy of SAR422459, a lentiviral vector providing addition of the normally functioning gene (Table 1). Completion of phase II is anticipated in 2017. In the meantime, Parker et al. have defined criteria for statistically significant changes in functional and structural measurements in Stargardt disease progression [65].

\subsection{Neovascular Age-Related Macular Degeneration}

Gene therapy has also been applied to acquired retinal disease (Table 1). Age-related macular degeneration (AMD) is the leading cause of visual impairment in the United States, and the neovascular form, or wet AMD (wAMD), is characterized by abnormal choroidal vessel proliferation behind the macula $[68,141]$. Over-secretion of vascular endothelial growth factor (VEGF) plays a key role in the pathogenesis of neovascular AMD, and the current standard of care includes the administration of intravitreal anti-VEGF inhibitors [142]. Gene therapy has a theoretical advantage, as long-lasting expression would reduce or eliminate the need for repeated injections of anti-VEGF inhibitors in 
patients. Lions Eye Institute (Perth, WA, Australia) is sponsoring a trial for subretinal delivery of rAAV.sFLT-1, and no serious ocular or systemic adverse events due to the vector were reported in phase I/IIa trials [68,70]. Two patients experienced mild eye and anterior chamber inflammation suspected to have been caused by rAAV.sFLT-1 administration, although the inflammation did resolve. While the cohort receiving gene therapy required fewer additional ranibizumab injections, post-hoc analysis revealed no significant differences in outcome measures between groups in the phase $2 \mathrm{a}$ study. This may be in part due to the low number of patients enrolled $(n=32)$, and future trials would be necessary to determine if rAAV.sFLT-1 is an efficacious adjunct to ranibizumab [70]. Similarly, Genzyme, a Sanofi company (Cambridge, MA, USA) is sponsoring a phase I safety and tolerability trial assessing intravitreal delivery of the same anti-VEGF gene therapy vector. Oxford BioMedica (Oxford, UK) has also initiated clinical trials for subretinal RetinoStat ${ }^{\circledR}$ (GEM study), a lentivirus containing angiostatic genes, angiostatin and endostatin, to prevent vessel growth and subsequent vision decline (Table 1). Campochiaro et al. reported results of the GEM study, which showed vector-containing gene therapy delivered by subretinal injection was well tolerated, and expression levels were maintained at last measurement, which was more than 2.5 years in eight subjects and more than 4 years in two subjects [75]. It remains to be seen if gene therapy will provide a viable treatment option and/or adjunct for wAMD. If efficacy is demonstrated, this may represent a paradigm shift in ophthalmic medicine, as gene therapy has traditionally been applied to monogenic diseases [70].

\section{Importance of Natural Disease Characterization}

The advent of clinical trials for inherited retinal disease has necessitated natural disease history studies for various degenerations. Although gene therapy trials use the contralateral eye as a control, it is important to study the rate of disease progression and the degree of symmetry between each eye to validate using the untreated eye as a control. Assessing disease progression rates from large cohort studies is additionally useful for identifying optimal functional and structural outcome measures [10]. Moreover, results from these studies aid investigators in deciding which patients are the best candidates for gene therapy. Although it can be difficult to complete a well-powered study given the low sample size of patients with rare degenerative diseases, several observational cohort studies are being attempted for a variety of retinal degenerations (Table 2).

Table 2. Clinical trials for natural disease characterization of retinal degenerations.

\begin{tabular}{|c|c|c|}
\hline & NCT ID \& Sponsor & Design (Gene of Interest) \\
\hline \multirow{3}{*}{$\begin{array}{l}\text { Leber Congenital } \\
\text { Amaurosis }\end{array}$} & $\begin{array}{l}\text { NCT02575430 } \\
\text { QLT Inc. } \\
\text { (Vancouver, BC, Canada) }\end{array}$ & Retrospective (LRAT \& RPE65) \\
\hline & $\begin{array}{l}\text { NCT02714816 } \\
\text { MeiraGTx UK II Ltd. } \\
\text { (New York, NY, USA) }\end{array}$ & Prospective (RPE65) \\
\hline & $\begin{array}{l}\text { NCT00422721 } \\
\text { Nantes University Hospital } \\
\text { (Nantes, France) }\end{array}$ & Prospective (RPE65) \\
\hline Choroideremia & $\begin{array}{l}\text { NCT02994368 } \\
\text { 4D Molecular Therapeutics } \\
\text { (Emeryville, CA, USA) }\end{array}$ & Prospective (REP-1) \\
\hline Achromatopsia & $\begin{array}{l}\text { NCT01846052 } \\
\text { Applied Genetic Technologies Corp. } \\
\text { (Alachua, FL, USA) }\end{array}$ & Prospective (CNGB3) \\
\hline $\begin{array}{l}\text { Leber Hereditary } \\
\text { Optic Neuropathy }\end{array}$ & $\begin{array}{l}\text { NCT02796274 } \\
\text { Santhera Pharmaceuticals } \\
\text { (Liestal, Switzerland) }\end{array}$ & $\begin{array}{l}\text { Retrospective (G11778A, G3460A, } \\
\text { and T14484C mtDNA mutations) }\end{array}$ \\
\hline
\end{tabular}


Table 2. Cont.

\begin{tabular}{|c|c|c|}
\hline & NCT ID \& Sponsor & Design (Gene of Interest) \\
\hline $\begin{array}{c}\text { X-linked } \\
\text { Retinoschisis }\end{array}$ & $\begin{array}{l}\text { NCT00055029 } \\
\text { National Eye Institute } \\
\text { (Bethesda, MD, USA) }\end{array}$ & Prospective (RS1) \\
\hline \multirow{5}{*}{$\begin{array}{c}\text { Retinitis } \\
\text { Pigmentosa }\end{array}$} & $\begin{array}{l}\text { NCT02759952 } \\
\text { STZ Eyetrial } \\
\text { (Tübingen, Germany) }\end{array}$ & Prospective $(P D E 6 A)$ \\
\hline & $\begin{array}{l}\text { NCT01021982 } \\
\text { Sheba Medical Center } \\
\text { (Ramat Gan, Israel) }\end{array}$ & Prospective \\
\hline & $\begin{array}{l}\text { NCT01949623 } \\
\text { Johns Hopkins University } \\
\text { (Baltimore, MD, USA) }\end{array}$ & Prospective biomarker study \\
\hline & $\begin{array}{l}\text { NCT02926092 } \\
\text { Shire } \\
\text { (Dublin, Ireland) }\end{array}$ & Prospective (RHO) \\
\hline & $\begin{array}{l}\text { NCT00784901 } \\
\text { National Taiwan University Hospital } \\
\text { (Taipei City, Taiwan) }\end{array}$ & Retrospective \\
\hline Usher Syndrome & $\begin{array}{l}\text { NCT00106743 } \\
\text { National Eye Institute } \\
\text { (Bethesda, MD, USA) }\end{array}$ & Prospective \\
\hline \multirow{3}{*}{ Stargardt Disease } & $\begin{array}{l}\text { NCT01977846 } \\
\text { Foundation Fighting Blindness } \\
\text { Clinical Research Institute } \\
\text { (Columbia, MD, USA) }\end{array}$ & $\begin{array}{l}\text { Retrospective \& Prospective } \\
(A B C A 4)\end{array}$ \\
\hline & $\begin{array}{l}\text { NCT02410122 } \\
\text { John Hopkins University } \\
\text { (Baltimore, MD, USA) }\end{array}$ & Prospective (PROM1) \\
\hline & $\begin{array}{l}\text { NCT01736293 } \\
\text { National Eye Institute } \\
\text { (Bethesda, MD, USA) }\end{array}$ & Prospective $(A B C A 4)$ \\
\hline
\end{tabular}

\section{CRISPR/Cas: Ophthalmic Genome Surgery of the Future?}

Clustered regularly interspaced short palindromic repeats (CRISPR) are present in bacterial and archaeal genomes and function to provide immunity against invading viruses [143-146]. The CRISPR locus contains integrated pieces of foreign DNA and encodes for a long transcript that is ultimately processed intracellularly to become CRISPR-derived RNA (crRNA). Consequently, crRNAs contain complementary sequences to the previously invading foreign DNA, and they can mediate a highly specific, nucleic-acid based adaptive immune system by complexing with CRISPR-associated (Cas) nucleases that induce double strand breaks (DSBs) [147]. Also within the CRISPR locus of a strain of Streptococcus pyogenes, there exists a necessary noncoding trans-activating crRNA (tracrRNA), which investigators combined with crRNA to form a chimeric crRNA-tracrRNA hybrid, termed guide RNA (gRNA) [148]. Cas9 was shown to effectively be directed to specific target sequences by custom-made gRNA in vitro, introducing a new genome-modifying toolkit which has revolutionized the field of genetic engineering [148].

Once a double-strand break occurs in the eukaryotic genome, either non-homologous end joining (NHEJ) or homology-directed repair (HDR) subsequently occurs to prevent cell death. NHEJ occurs with less fidelity, as the two broken ends are directly reconnected with the possibility of insertions and deletions, termed 'indels', often yielding a dysfunctional gene product. In the case of HDR, the homologous chromosome serves as a template to ensure the broken strands contain the correct sequence before ligation [149]. DSBs caused by the CRISPRn/Cas system (where ' $n$ ' denotes traditional 
CRISPR, namely to distinguish it from newer techniques, which will be discussed in subsequent text) at a desired location induce these endogenous DNA repair mechanisms. Thus, applications of CRISPRn/Cas have made use of the NHEJ and HDR that occurs after induction of DSBs. NHEJ occurs more frequently compared to HDR, making the gene 'knock-out' strategy more readily feasible thus far [150]. However, there is also 'knock-in' strategies that supplement a donor template in addition to the gRNA and Cas protein, which consequently promotes gene repair via the HDR pathway [151]. Previous genomic engineering also required HDR to occur; however, these methods were dependent on the low incidence of DNA damage, whereas CRISPRn creates DSBs with impressive specificity [152].

\subsection{Applications to Retinal Disease}

Retinal disease has been at the forefront of previous gene-based therapy research and, for the same reasons, may prove to be amenable to CRISPRn/Cas in vivo applications. Of note, Bakondi et al. used CRISPRn/Cas9 to ablate the mutant rhodopsin gene containing an S334ter mutation in a rat model of dominant retinitis pigmentosa. Sub-retinal delivery of gRNA and Cas9 with subsequent electroporation was sufficient to ablate the gain-of-function mutation and proved highly specific, as function of the wild type allele was unaffected. Phenotypic rescue was evident with immunohistology, showing robust photoreceptor and retinal synapse preservation [153]. This study marked the first instance where a dominantly inherited mutant allele was amenable to ablation through CRISPRn/Cas in vivo. In addition to this rescue experiment, CRISPRn/Cas has already been used to validate disease-causing pathogenic gene mutations in the retina $[154,155]$ and identify genes important for normal retinal function and development [156-158].

Repurposing the prokaryotic CRISPRn/Cas adaptive immune system to perform gene-editing in human cells has also been accomplished in vitro [159-162], representing a major milestone in molecular biology [150]. For example, induced pluripotent stem cells (iPSCs) obtained from skin fibroblasts of a patient with $\mathrm{X}$-linked retinitis pigmentosa caused by an RPGR point mutation were subjected to CRISPRn/Cas9 gene editing, producing corrected graft cells [163]. In theory, these corrected iPSCs can be used for autologous cell transplantation, which will circumvent the need for immunosuppression. For mature retinal cells, in vivo delivery experiments have been done with AAV2, which provided Cas9 and sgRNA that targeted the yellow fluorescent protein (YFP) gene expressed in a transgenic mouse [164]. This strategy effectively decreased the number of cells expressing YFP in the retina without affecting retinal function, suggesting that applying CRISPRn/Cas to the mature retina in vivo is feasible.

Despite rapid developments in CRISPR/Cas genome engineering, various challenges persist. Off-target effects remain a concern for future therapeutic applications, as mutagenesis of non-desired sites can occur at a high frequency [165]. To circumvent this issue, a catalytic domain of Cas9 was reengineered in such a way that the nuclease could function as a nickase, which induces a single strand break (SSB) that, in the event of an off-targeting event, will likely be less deleterious (Cas9n) [166-168]. To obtain a DSB at the desired location using Cas9n, two gRNAs are used that complement opposite strands of the target sequence. This improves specificity by more than an order of magnitude [166-168]. Another study optimized the reduction of off-target effects in human cells, characterizing the effects of base pair mismatch location and number in the gRNA, and the advantages of titrating the dosage of Cas9 and gRNA [169]. Delivery poses an additional challenge for the clinical translation of CRISPR/Cas to human disease. While the most frequently used Cas protein has a cDNA sequence that can be packaged into $\mathrm{AAV}$, its small carrying capacity does not allow much additional room for other elements, as in the case of gene 'knock-in' where a donor template is required.

\subsection{New Developments in CRISPR-Based Genome Engineering}

While CRISPR in its traditional form has become a staple of most genetic labs, its utility has significantly diversified as researchers began developing ways to repurpose the technology. Recently, a strategy for reversible CRISPR-based gene editing was developed and termed CRISPR interference 
(CRISPRi). This technique employs a catalytically dead Cas (dCas) protein, which can bind but not cleave DNA [170]. Thus, the dCas-sgRNA complex binds to the target gene and impedes transcription by preventing RNA polymerase from binding to the promoter region or from elongating a transcript [170]. In microbial organisms like Escherichia coli, simply replacing Cas with dCas is typically sufficient to prevent transcription, but in mammalian cells, the efficiency of inhibition is significantly enhanced by fusing the dCas with a repressor domain, the Krüppel-associated box (KRAB) domain being one commonly used repressor [171]. This arrangement creates a highly programmable system that can alter gene expression at the transcription level. The technique holds many similarities to the conventionally used RNA interference (RNAi) system, but it has been shown to be highly sensitive to mismatches between the sgRNA and target sequence, thus reducing off-targeting effects compared to RNAi $[172,173]$.

While KRAB domains can be fused with dCas, other molecules have been added to the endonuclease to alter its activity in the opposite fashion. By fusing transcription activating domains with dCas, gene expression can be enhanced rather than inhibited. This technique is known as CRISPR-on or more commonly, CRISPR activation (CRISPRa) [174], and it typically involves fusion of dCas with transactivator domain VP16, among others [175-177]. By localizing the dCas to the promoter region of a gene, VP16 can upregulate the gene's expression. While only minimal activation has been obtained using this strategy, designing multiple sgRNAs for the same promoter region has been shown to significantly augment efficiency [178]. Efforts are underway to further enhance the efficiency of activation by recruiting additional activation domains, for example, and there remains great enthusiasm for the future applications of this technique.

One of the newest developments in CRISPR arose from researchers seeking a means to create single-nucleotide alterations without inducing DSBs $[179,180]$. They did so by fusing dCas with a rodent cytidine deaminase called APOBEC1, which converts cytosine to uracil. Cells transfected with the new $\mathrm{dCas} /$ deaminase fusion protein undergo a single cytosine to uracil conversion, which is subsequently corrected to thymine by DNA correction mechanisms or during replication. Komor et al. created several generations of the fusion protein to optimize its efficiency, and they dubbed the final generation BE3. The optimized BE3 protein replaces dCas with a nickase, which, as mentioned previously, is a catalytically active Cas protein that induces only a SSB. Although dCas results in the fewest number of insertions and deletions (indels) in the genome due to the lack of a cleavage event, nickase-induced SSBs also result in much fewer indels compared to the number accrued following a DSB. The rationale for using a nickase over dCas was that by nicking the non-edited homologous strand, the cell perceives the strand to be newly synthesized, which signals for DNA repair proteins to correct it for errors using the edited target strand as a template. In this manner, both strands will be edited despite only one having been cleaved. BE3 editing efficiency was further enhanced by fusing Cas nickase with an inhibitor of the naturally occurring base excision repair process, which removes uracil nucleotides from DNA. The overall efficiency of the system combined with the reduction in the frequency of indels and off-targeting effects represent a considerable advancement and evolution from the traditional application of CRISPR.

When juxtaposing all four techniques, CRISPRi and CRISPRa distinguish themselves from traditional CRISPRn/Cas or BE3 approaches because they act at the transcriptome level, preserving the original genome. This allows the techniques to be reversible, which confers both benefits and detriments. The transient effects of CRISPRi/a impart a considerable advantage over CRISPRn in obtaining FDA approval for use in clinical trials, since the patient's own genome will remain intact and unaltered. However, for patients with inherited retinal conditions, for example, multiple subretinal injections to re-administer the Cas/sgRNA-containing vectors could be harmful and impractical. A long-term, single intervention would be preferable for these patients, in which case CRISPRn or the BE3 system might be a stronger alternative. Additionally, despite the many advantages of the BE3 technology over traditional CRISPRn/Cas, such as reduced off-targeting effects and higher overall efficiency of editing, the current BE3 strategy is limited in its applicability. Until conversions can be 
made between adenine and guanine as well, the breadth of diseases that can be corrected using this technique is restricted to a select subset. However, CRISPR technology has continued to advance at a rapid pace, and it is likely that soon these techniques will be employed extensively in genetics research and across multiple fields of medicine.

Acknowledgments: Jonas Children's Vision Care, and Bernard \& Shirlee Brown Glaucoma Laboratory are supported by the National Institutes of Health [5P30EY019007, R01EY018213, R01EY024698, R01EY026682, R21AG050437], National Cancer Institute Core [5P30CA013696], the Research to Prevent Blindness (RPB) Physician-Scientist Award, unrestricted funds from RPB, New York, NY, USA. J.D.S. is supported by the RPB Medical Student Research Fellowship. T.C. is supported by the International Council of Ophthalmology-Retina Research Foundation Helmerich Fellowship, honoring W. H. Helmerich III. S.H.T. is a member of the RD-CURE Consortium and is supported by the Tistou and Charlotte Kerstan Foundation, the Schneeweiss Stem Cell Fund, New York State [C029572], the Foundation Fighting Blindness New York Regional Research Center Grant [C-NY05-0705-0312], the Joel Hoffman Fund, the Professor Gertrude Rothschild Stem Cell Foundation, and the Gebroe Family Foundation.

Author Contributions: J.D.S. and S.J. performed literature searches and wrote the manuscript. T.C. assisted in writing the manuscript. S.H.T. oversaw all aspects of manuscript preparation and holds final responsibility for contained information and the decision to submit for publication.

Conflicts of Interest: The authors declare no conflicts of interest.

\section{References}

1. Raper, S.E.; Chirmule, N.; Lee, F.S.; Wivel, N.A.; Bagg, A.; Gao, G.P.; Wilson, J.M.; Batshaw, M.L. Fatal systemic inflammatory response syndrome in a ornithine transcarbamylase deficient patient following adenoviral gene transfer. Mol. Genet. Metab. 2003, 80, 148-158. [CrossRef] [PubMed]

2. Kohn, D.B.; Sadelain, M.; Glorioso, J.C. Occurrence of leukaemia following gene therapy of X-linked SCID. Nat. Rev. Cancer 2003, 3, 477-488. [CrossRef] [PubMed]

3. Bennett, J.; Tanabe, T.; Sun, D.; Zeng, Y.; Kjeldbye, H.; Gouras, P.; Maguire, A.M. Photoreceptor cell rescue in retinal degeneration $(r d)$ mice by in vivo gene therapy. Nat. Med. 1996, 2, 649-654. [CrossRef] [PubMed]

4. Acland, G.M.; Aguirre, G.D.; Ray, J.; Zhang, Q.; Aleman, T.S.; Cideciyan, A.V.; Pearce-Kelling, S.E.; Anand, V.; Zeng, Y.; Maguire, A.M.; et al. Gene therapy restores vision in a canine model of childhood blindness. Nat. Genet. 2001, 28, 92-95. [CrossRef] [PubMed]

5. Bainbridge, J.W.; Smith, A.J.; Barker, S.S.; Robbie, S.; Henderson, R.; Balaggan, K.; Viswanathan, A.; Holder, G.E.; Stockman, A.; Tyler, N.; et al. Effect of gene therapy on visual function in Leber's congenital amaurosis. N. Engl. J. Med. 2008, 358, 2231-2239. [CrossRef] [PubMed]

6. Hauswirth, W.W.; Aleman, T.S.; Kaushal, S.; Cideciyan, A.V.; Schwartz, S.B.; Wang, L.; Conlon, T.J.; Boye, S.L.; Flotte, T.R.; Byrne, B.J.; et al. Treatment of Leber congenital amaurosis due to RPE65 mutations by ocular subretinal injection of adeno-associated virus gene vector: Short-term results of a phase I trial. Hum. Gene Ther. 2008, 19, 979-990. [CrossRef] [PubMed]

7. Maguire, A.M.; Simonelli, F.; Pierce, E.A.; Pugh, E.N., Jr.; Mingozzi, F.; Bennicelli, J.; Banfi, S.; Marshall, K.A.; Testa, F.; Surace, E.M.; et al. Safety and efficacy of gene transfer for Leber's congenital amaurosis. N. Engl. J. Med. 2008, 358, 2240-2248. [CrossRef] [PubMed]

8. Boye, S.; Boye, S. Genetic therapies for inheritied retinal disease: Adeno-associated viruses have shown promise. Retin. Physician 2015, 12, 19-24.

9. Lin, M.K.; Tsai, Y.T.; Tsang, S.H. Emerging treatments for retinitis pigmentosa: Genes and stem cells, as well as new electronic and medical therapies, are gaining ground. Retin. Physician 2015, 12, 52-70. [PubMed]

10. Sujirakul, T.; Lin, M.K.; Duong, J.; Wei, Y.; Lopez-Pintado, S.; Tsang, S.H. Multimodal imaging of central retinal disease progression in a 2-year mean follow-up of retinitis pigmentosa. Am. J. Ophthalmol. 2015, 160, 786-798. [CrossRef] [PubMed]

11. Liu, G.; Liu, X.; Li, H.; Du, Q.; Wang, F. Optical coherence tomographic analysis of retina in retinitis pigmentosa patients. Ophthalmic Res. 2016, 56, 111-122. [CrossRef] [PubMed]

12. Chalam, K.V.; Sambhav, K. Optical coherence tomography angiography in retinal diseases. J. Ophthalmic Vis. Res. 2016, 11, 84-92. [CrossRef] [PubMed] 
13. Choi, W.; Mohler, K.J.; Potsaid, B.; Lu, C.D.; Liu, J.J.; Jayaraman, V.; Cable, A.E.; Duker, J.S.; Huber, R.; Fujimoto, J.G. Choriocapillaris and choroidal microvasculature imaging with ultrahigh speed OCT angiography. PLoS ONE 2013, 8, e81499. [CrossRef] [PubMed]

14. Kim, D.Y.; Fingler, J.; Zawadzki, R.J.; Park, S.S.; Morse, L.S.; Schwartz, D.M.; Fraser, S.E.; Werner, J.S. Optical imaging of the chorioretinal vasculature in the living human eye. Proc. Natl. Acad. Sci. USA 2013, 110, 14354-14359. [CrossRef] [PubMed]

15. Schwartz, D.M.; Fingler, J.; Kim, D.Y.; Zawadzki, R.J.; Morse, L.S.; Park, S.S.; Fraser, S.E.; Werner, J.S. Phase-variance optical coherence tomography: A technique for noninvasive angiography. Ophthalmology 2014, 121, 180-187. [CrossRef] [PubMed]

16. Spaide, R.F.; Klancnik, J.M., Jr.; Cooney, M.J. Retinal vascular layers imaged by fluorescein angiography and optical coherence tomography angiography. JAMA Ophthalmol. 2015, 133, 45-50. [CrossRef] [PubMed]

17. Fakin, A.; Jarc-Vidmar, M.; Glavac, D.; Bonnet, C.; Petit, C.; Hawlina, M. Fundus autofluorescence and optical coherence tomography in relation to visual function in Usher syndrome type 1 and 2. Vis. Res. 2012, 75, 60-70. [CrossRef] [PubMed]

18. Greenstein, V.C.; Duncker, T.; Holopigian, K.; Carr, R.E.; Greenberg, J.P.; Tsang, S.H.; Hood, D.C. Structural and functional changes associated with normal and abnormal fundus autofluorescence in patients with retinitis pigmentosa. Retina 2012, 32, 349-357. [CrossRef] [PubMed]

19. Lenassi, E.; Saihan, Z.; Cipriani, V.; Le Quesne Stabej, P.; Moore, A.T.; Luxon, L.M.; Bitner-Glindzicz, M.; Webster, A.R. Natural history and retinal structure in patients with Usher syndrome type 1 owing to MYO7A mutation. Ophthalmology 2014, 121, 580-587. [CrossRef] [PubMed]

20. Lima, L.H.; Burke, T.; Greenstein, V.C.; Chou, C.L.; Cella, W.; Yannuzzi, L.A.; Tsang, S.H. Progressive constriction of the hyperautofluorescent ring in retinitis pigmentosa. Am. J. Ophthalmol. 2012, 153, 718-727. [CrossRef] [PubMed]

21. Oishi, A.; Ogino, K.; Makiyama, Y.; Nakagawa, S.; Kurimoto, M.; Yoshimura, N. Wide-field fundus autofluorescence imaging of retinitis pigmentosa. Ophthalmology 2013, 120, 1827-1834. [CrossRef] [PubMed]

22. Popovic, P.; Jarc-Vidmar, M.; Hawlina, M. Abnormal fundus autofluorescence in relation to retinal function in patients with retinitis pigmentosa. Graefes Arch. Clin. Exp. Ophthalmol. 2005, 243, 1018-1027. [CrossRef] [PubMed]

23. Ramachandran, R.; Zhou, L.; Locke, K.G.; Birch, D.G.; Hood, D.C. A comparison of methods for tracking progression in X-linked retinitis pigmentosa using frequency domain OCT. Transl. Vis. Sci. Technol. 2013, 2, 5. [CrossRef] [PubMed]

24. Robson, A.G.; Lenassi, E.; Saihan, Z.; Luong, V.A.; Fitzke, F.W.; Holder, G.E.; Webster, A.R. Comparison of fundus autofluorescence with photopic and scotopic fine matrix mapping in patients with retinitis pigmentosa: 4- to 8-year follow-up. Investig. Ophthalmol. Vis. Sci. 2012, 53, 6187-6195. [CrossRef] [PubMed]

25. Robson, A.G.; Saihan, Z.; Jenkins, S.A.; Fitzke, F.W.; Bird, A.C.; Webster, A.R.; Holder, G.E. Functional characterisation and serial imaging of abnormal fundus autofluorescence in patients with retinitis pigmentosa and normal visual acuity. Br. J. Ophthalmol. 2006, 90, 472-479. [CrossRef] [PubMed]

26. Sujirakul, T.; Davis, R.; Erol, D.; Zhang, L.; Schillizzi, G.; Royo-Dujardin, L.; Shen, S.; Tsang, S. Bilateral concordance of the fundus hyperautofluorescent ring in typical retinitis pigmentosa patients. Ophthalmic Genet. 2015, 36, 113-122. [CrossRef] [PubMed]

27. Wakabayashi, T.; Sawa, M.; Gomi, F.; Tsujikawa, M. Correlation of fundus autofluorescence with photoreceptor morphology and functional changes in eyes with retinitis pigmentosa. Acta Ophthalmol. 2010, 88, e177-e183. [CrossRef] [PubMed]

28. Sonoda, K.H.; Sakamoto, T.; Qiao, H.; Hisatomi, T.; Oshima, T.; Tsutsumi-Miyahara, C.; Exley, M.; Balk, S.P.; Taniguchi, M.; Ishibashi, T. The analysis of systemic tolerance elicited by antigen inoculation into the vitreous cavity: Vitreous cavity-associated immune deviation. Immunology 2005, 116, 390-399. [CrossRef] [PubMed]

29. Bennett, J.; Wellman, J.; Marshall, K.A.; McCague, S.; Ashtari, M.; DiStefano-Pappas, J.; Elci, O.U.; Chung, D.C.; Sun, J.; Wright, J.F.; et al. Safety and durability of effect of contralateral-eye administration of AAV2 gene therapy in patients with childhood-onset blindness caused by RPE65 mutations: A follow-on phase 1 trial. Lancet 2016, 388, 661-672. [CrossRef]

30. Ashtari, M.; Cyckowski, L.L.; Monroe, J.F.; Marshall, K.A.; Chung, D.C.; Auricchio, A.; Simonelli, F.; Leroy, B.P.; Maguire, A.M.; Shindler, K.S.; et al. The human visual cortex responds to gene therapy-mediated recovery of retinal function. J. Clin. Investig. 2011, 121, 2160-2168. [CrossRef] [PubMed] 
31. Bennett, J.; Ashtari, M.; Wellman, J.; Marshall, K.A.; Cyckowski, L.L.; Chung, D.C.; McCague, S.; Pierce, E.A.; Chen, Y.; Bennicelli, J.L.; et al. AAV2 gene therapy readministration in three adults with congenital blindness. Sci. Transl. Med. 2012, 4, 120ra115. [CrossRef] [PubMed]

32. Maguire, A.M.; High, K.A.; Auricchio, A.; Wright, J.F.; Pierce, E.A.; Testa, F.; Mingozzi, F.; Bennicelli, J.L.; Ying, G.S.; Rossi, S.; et al. Age-dependent effects of RPE65 gene therapy for Leber's congenital amaurosis: A phase 1 dose-escalation trial. Lancet 2009, 374, 1597-1605. [CrossRef]

33. Simonelli, F.; Maguire, A.M.; Testa, F.; Pierce, E.A.; Mingozzi, F.; Bennicelli, J.L.; Rossi, S.; Marshall, K.; Banfi, S.; Surace, E.M.; et al. Gene therapy for Leber's congenital amaurosis is safe and effective through 1.5 years after vector administration. Mol. Ther. 2010, 18, 643-650. [CrossRef] [PubMed]

34. Bainbridge, J.W.; Mehat, M.S.; Sundaram, V.; Robbie, S.J.; Barker, S.E.; Ripamonti, C.; Georgiadis, A.; Mowat, F.M.; Beattie, S.G.; Gardner, P.J.; et al. Long-term effect of gene therapy on Leber's congenital amaurosis. N. Engl. J. Med. 2015, 372, 1887-1897. [CrossRef] [PubMed]

35. Ripamonti, C.; Henning, G.B.; Robbie, S.J.; Sundaram, V.; van den Born, L.I.; Casteels, I.; de Ravel, T.J.; Moore, A.T.; Smith, A.J.; Bainbridge, J.W.; et al. Spectral sensitivity measurements reveal partial success in restoring missing rod function with gene therapy. J. Vis. 2015, 15, 20. [CrossRef] [PubMed]

36. Stieger, K. Tgaag76, an adeno-associated virus delivered gene therapy for the potential treatment of vision loss caused by RPE65 gene abnormalities. Curr. Opin. Mol. Ther. 2010, 12, 471-477. [PubMed]

37. Weleber, R.G.; Pennesi, M.E.; Wilson, D.J.; Kaushal, S.; Erker, L.R.; Jensen, L.; McBride, M.T.; Flotte, T.R.; Humphries, M.; Calcedo, R.; et al. Results at 2 years after gene therapy for RPE65-deficient Leber congenital amaurosis and severe early-childhood-onset retinal dystrophy. Ophthalmology 2016, 123, 1606-1620. [CrossRef] [PubMed]

38. Georgiadis, A.; Duran, Y.; Ribeiro, J.; Abelleira-Hervas, L.; Robbie, S.J.; Sunkel-Laing, B.; Fourali, S.; Gonzalez-Cordero, A.; Cristante, E.; Michaelides, M.; et al. Development of an optimized AAV2/5 gene therapy vector for Leber congenital amaurosis owing to defects in RPE65. Gene Ther. 2016, 23, 857-862. [CrossRef] [PubMed]

39. Cideciyan, A.V.; Aguirre, G.K.; Jacobson, S.G.; Butt, O.H.; Schwartz, S.B.; Swider, M.; Roman, A.J.; Sadigh, S.; Hauswirth, W.W. Pseudo-fovea formation after gene therapy for RPE65-LCA. Investig. Ophthalmol. Vis. Sci. 2014, 56, 526-537. [CrossRef] [PubMed]

40. Jacobson, S.G.; Cideciyan, A.V.; Ratnakaram, R.; Heon, E.; Schwartz, S.B.; Roman, A.J.; Peden, M.C.; Aleman, T.S.; Boye, S.L.; Sumaroka, A.; et al. Gene therapy for leber congenital amaurosis caused by RPE65 mutations: Safety and efficacy in 15 children and adults followed up to 3 years. Arch. Ophthalmol. 2012, 130, 9-24. [CrossRef] [PubMed]

41. Jacobson, S.G.; Cideciyan, A.V.; Roman, A.J.; Sumaroka, A.; Schwartz, S.B.; Heon, E.; Hauswirth, W.W. Improvement and decline in vision with gene therapy in childhood blindness. N. Engl. J. Med. 2015, 372, 1920-1926. [CrossRef] [PubMed]

42. Jacobson, S.G.; Boye, S.L.; Aleman, T.S.; Conlon, T.J.; Zeiss, C.J.; Roman, A.J.; Cideciyan, A.V.; Schwartz, S.B.; Komaromy, A.M.; Doobrajh, M.; et al. Safety in nonhuman primates of ocular AAV2-RPE65, a candidate treatment for blindness in Leber congenital amaurosis. Hum. Gene Ther. 2006, 17, 845-858. [CrossRef] [PubMed]

43. MacLaren, R.E.; Groppe, M.; Barnard, A.R.; Cottriall, C.L.; Tolmachova, T.; Seymour, L.; Clark, K.R.; During, M.J.; Cremers, F.P.; Black, G.C.; et al. Retinal gene therapy in patients with choroideremia: Initial findings from a phase $1 / 2$ clinical trial. Lancet 2014, 383, 1129-1137. [CrossRef]

44. Seitz, I.P.; Zhour, A.; Kohl, S.; Llavona, P.; Peter, T.; Wilhelm, B.; Zrenner, E.; Ueffing, M.; Bartz-Schmidt, K.U.; Fischer, M.D. Multimodal assessment of choroideremia patients defines pre-treatment characteristics. Graefes Arch. Clin. Exp. Ophthalmol. 2015, 253, 2143-2150. [CrossRef] [PubMed]

45. Xue, K.; Oldani, M.; Jolly, J.K.; Edwards, T.L.; Groppe, M.; Downes, S.M.; MacLaren, R.E. Correlation of optical coherence tomography and autofluorescence in the outer retina and choroid of patients with choroideremia. Investig. Ophthalmol. Vis. Sci. 2016, 57, 3674-3684. [CrossRef] [PubMed]

46. Komaromy, A.M.; Alexander, J.J.; Rowlan, J.S.; Garcia, M.M.; Chiodo, V.A.; Kaya, A.; Tanaka, J.C.; Acland, G.M.; Hauswirth, W.W.; Aguirre, G.D. Gene therapy rescues cone function in congenital achromatopsia. Hum. Mol. Genet. 2010, 19, 2581-2593. [CrossRef] [PubMed] 
47. Ye, G.J.; Budzynski, E.; Sonnentag, P.; Nork, T.M.; Miller, P.E.; McPherson, L.; Ver Hoeve, J.N.; Smith, L.M.; Arndt, T.; Mandapati, S.; et al. Safety and biodistribution evaluation in CNGB3-deficient mice of rAAV2tYF-PR1.7-hCNGB3, a recombinant AAV vector for treatment of achromatopsia. Hum. Gene Ther. Clin. Dev. 2016, 27, 27-36. [CrossRef] [PubMed]

48. Ye, G.J.; Budzynski, E.; Sonnentag, P.; Nork, T.M.; Miller, P.E.; Sharma, A.K.; Ver Hoeve, J.N.; Smith, L.M.; Arndt, T.; Calcedo, R.; et al. Safety and biodistribution evaluation in cynomolgus macaques of rAAV2tYF-PR1.7-hCNGB3, a recombinant AAV vector for treatment of achromatopsia. Hum. Gene Ther. Clin. Dev. 2016, 27, 37-48. [CrossRef] [PubMed]

49. Marangoni, D.; Wu, Z.; Wiley, H.E.; Zeiss, C.J.; Vijayasarathy, C.; Zeng, Y.; Hiriyanna, S.; Bush, R.A.; Wei, L.L.; Colosi, P.; et al. Preclinical safety evaluation of a recombinant AAV8 vector for X-linked retinoschisis after intravitreal administration in rabbits. Hum. Gene Ther. Clin. Dev. 2014, 25, 202-211. [CrossRef] [PubMed]

50. Marangoni, D.; Bush, R.A.; Zeng, Y.; Wei, L.L.; Ziccardi, L.; Vijayasarathy, C.; Bartoe, J.T.; Palyada, K.; Santos, M.; Hiriyanna, S.; et al. Ocular and systemic safety of a recombinant AAV8 vector for X-linked retinoschisis gene therapy: GLP studies in rabbits and RS1-KO mice. Mol. Ther. Methods Clin. Dev. 2016, 5, 16011. [CrossRef] [PubMed]

51. Bush, R.A.; Zeng, Y.; Colosi, P.; Kjellstrom, S.; Hiriyanna, S.; Vijayasarathy, C.; Santos, M.; Li, J.; Wu, Z.; Sieving, P.A. Preclinical dose-escalation study of intravitreal AAV-RS1 gene therapy in a mouse model of X-linked retinoschisis: Dose-dependent expression and improved retinal structure and function. Hum. Gene Ther. 2016, 27, 376-389. [CrossRef] [PubMed]

52. Zeng, Y.; Petralia, R.S.; Vijayasarathy, C.; Wu, Z.; Hiriyanna, S.; Song, H.; Wang, Y.X.; Sieving, P.A.; Bush, R.A. Retinal structure and gene therapy outcome in retinoschisin-deficient mice assessed by spectral-domain optical coherence tomography. Investig. Ophthalmol. Vis. Sci. 2016, 57, OCT277-OCT287. [CrossRef] [PubMed]

53. Ye, G.J.; Budzynski, E.; Sonnentag, P.; Miller, P.E.; Sharma, A.K.; Ver Hoeve, J.N.; Howard, K.; Knop, D.R.; Neuringer, M.; McGill, T.; et al. Safety and biodistribution evaluation in cynomolgus macaques of rAAV2tYF-CB-hRS1, a recombinant adeno-associated virus vector expressing retinoschisin. Hum. Gene Ther. Clin. Dev. 2015, 26, 165-176. [CrossRef] [PubMed]

54. Ye, G.J.; Conlon, T.; Erger, K.; Sonnentag, P.; Sharma, A.K.; Howard, K.; Knop, D.R.; Chulay, J.D. Safety and biodistribution evaluation of rAAV2tYF-CB-hRS1, a recombinant adeno-associated virus vector expressing retinoschisin, in RS1-deficient mice. Hum. Gene Ther. Clin. Dev. 2015, 26, 177-184. [CrossRef] [PubMed]

55. Cwerman-Thibault, H.; Augustin, S.; Lechauve, C.; Ayache, J.; Ellouze, S.; Sahel, J.A.; Corral-Debrinski, M. Nuclear expression of mitochondrial ND4 leads to the protein assembling in complex I and prevents optic atrophy and visual loss. Mol. Ther. Methods Clin. Dev. 2015, 2, 15003. [CrossRef] [PubMed]

56. Koilkonda, R.; Yu, H.; Talla, V.; Porciatti, V.; Feuer, W.J.; Hauswirth, W.W.; Chiodo, V.; Erger, K.E.; Boye, S.L.; Lewin, A.S.; et al. LHON gene therapy vector prevents visual loss and optic neuropathy induced by G11778A mutant mitochondrial DNA: Biodistribution and toxicology profile. Investig. Ophthalmol. Vis. Sci. 2014, 55, 7739-7753. [CrossRef] [PubMed]

57. Koilkonda, R.D.; Yu, H.; Chou, T.H.; Feuer, W.J.; Ruggeri, M.; Porciatti, V.; Tse, D.; Hauswirth, W.W.; Chiodo, V.; Boye, S.L.; et al. Safety and effects of the vector for the Leber hereditary optic neuropathy gene therapy clinical trial. JAMA Ophthalmol. 2014, 132, 409-420. [CrossRef] [PubMed]

58. Feuer, W.J.; Schiffman, J.C.; Davis, J.L.; Porciatti, V.; Gonzalez, P.; Koilkonda, R.D.; Yuan, H.; Lalwani, A.; Lam, B.L.; Guy, J. Gene therapy for Leber hereditary optic neuropathy: Initial results. Ophthalmology 2016, 123, 558-570. [CrossRef] [PubMed]

59. Wan, X.; Pei, H.; Zhao, M.J.; Yang, S.; Hu, W.K.; He, H.; Ma, S.Q.; Zhang, G.; Dong, X.Y.; Chen, C.; et al. Efficacy and safety of rAAV2-ND4 treatment for Leber's hereditary optic neuropathy. Sci. Rep. 2016, 6, 21587. [CrossRef] [PubMed]

60. Bi, A.; Cui, J.; Ma, Y.P.; Olshevskaya, E.; Pu, M.; Dizhoor, A.M.; Pan, Z.H. Ectopic expression of a microbial-type rhodopsin restores visual responses in mice with photoreceptor degeneration. Neuron 2006, 50, 23-33. [CrossRef] [PubMed]

61. Ivanova, E.; Hwang, G.S.; Pan, Z.H.; Troilo, D. Evaluation of AAV-mediated expression of Chop2-GFP in the marmoset retina. Investig. Ophthalmol. Vis. Sci. 2010, 51, 5288-5296. [CrossRef] [PubMed] 
62. Ghazi, N.G.; Abboud, E.B.; Nowilaty, S.R.; Alkuraya, H.; Alhommadi, A.; Cai, H.; Hou, R.; Deng, W.T.; Boye, S.L.; Almaghamsi, A.; et al. Treatment of retinitis pigmentosa due to MERTK mutations by ocular subretinal injection of adeno-associated virus gene vector: Results of a phase I trial. Hum. Genet. 2016, 135, 327-343. [CrossRef] [PubMed]

63. Conlon, T.J.; Deng, W.T.; Erger, K.; Cossette, T.; Pang, J.J.; Ryals, R.; Clement, N.; Cleaver, B.; McDoom, I.; Boye, S.E.; et al. Preclinical potency and safety studies of an AAV2-mediated gene therapy vector for the treatment of MERTK associated retinitis pigmentosa. Hum. Gene Ther. Clin. Dev. 2013, 24, 23-28. [CrossRef] [PubMed]

64. Zallocchi, M.; Binley, K.; Lad, Y.; Ellis, S.; Widdowson, P.; Iqball, S.; Scripps, V.; Kelleher, M.; Loader, J.; Miskin, J.; et al. EIAV-based retinal gene therapy in the shaker1 mouse model for Usher syndrome type 1B: Development of UshStat. PLoS ONE 2014, 9, e94272. [CrossRef] [PubMed]

65. Parker, M.A.; Choi, D.; Erker, L.R.; Pennesi, M.E.; Yang, P.; Chegarnov, E.N.; Steinkamp, P.N.; Schlechter, C.L.; Dhaenens, C.M.; Mohand-Said, S.; et al. Test-retest variability of functional and structural parameters in patients with Stargardt disease participating in the SAR422459 gene therapy trial. Transl. Vis. Sci. Technol. 2016, 5, 10. [CrossRef] [PubMed]

66. Binley, K.; Widdowson, P.; Loader, J.; Kelleher, M.; Iqball, S.; Ferrige, G.; de Belin, J.; Carlucci, M.; Angell-Manning, D.; Hurst, F.; et al. Transduction of photoreceptors with equine infectious anemia virus lentiviral vectors: Safety and biodistribution of stargen for Stargardt disease. Investig. Ophthalmol. Vis. Sci. 2013, 54, 4061-4071. [CrossRef] [PubMed]

67. Kong, J.; Kim, S.R.; Binley, K.; Pata, I.; Doi, K.; Mannik, J.; Zernant-Rajang, J.; Kan, O.; Iqball, S.; Naylor, S.; et al. Correction of the disease phenotype in the mouse model of Stargardt disease by lentiviral gene therapy. Gene Ther. 2008, 15, 1311-1320. [CrossRef] [PubMed]

68. Rakoczy, E.P.; Lai, C.M.; Magno, A.L.; Wikstrom, M.E.; French, M.A.; Pierce, C.M.; Schwartz, S.D.; Blumenkranz, M.S.; Chalberg, T.W.; Degli-Esposti, M.A.; et al. Gene therapy with recombinant adeno-associated vectors for neovascular age-related macular degeneration: 1 year follow-up of a phase 1 randomised clinical trial. Lancet 2015, 386, 2395-2403. [CrossRef]

69. Constable, I.J.; Blumenkranz, M.S.; Schwartz, S.D.; Barone, S.; Lai, C.M.; Rakoczy, E.P. Gene therapy for age-related macular degeneration. Asia Pac. J. Ophthalmol. 2016, 5, 300-303. [CrossRef] [PubMed]

70. Constable, I.J.; Pierce, C.M.; Lai, C.M.; Magno, A.L.; Degli-Esposti, M.A.; French, M.A.; McAllister, I.L.; Butler, S.; Barone, S.B.; Schwartz, S.D.; et al. Phase 2a randomized clinical trial: Safety and post hoc analysis of subretinal rAAV.sFlt-1 for wet age-related macular degeneration. EBioMedicine 2016, 14, 168-175. [CrossRef] [PubMed]

71. Lukason, M.; DuFresne, E.; Rubin, H.; Pechan, P.; Li, Q.; Kim, I.; Kiss, S.; Flaxel, C.; Collins, M.; Miller, J.; et al. Inhibition of choroidal neovascularization in a nonhuman primate model by intravitreal administration of an AAV2 vector expressing a novel anti-VEGF molecule. Mol. Ther. 2011, 19, 260-265. [CrossRef] [PubMed]

72. Maclachlan, T.K.; Lukason, M.; Collins, M.; Munger, R.; Isenberger, E.; Rogers, C.; Malatos, S.; Dufresne, E.; Morris, J.; Calcedo, R.; et al. Preclinical safety evaluation of AAV2-sFLT01-A gene therapy for age-related macular degeneration. Mol. Ther. 2011, 19, 326-334. [CrossRef] [PubMed]

73. Pecen, P.E.; Kaiser, P.K. Current phase $1 / 2$ research for neovascular age-related macular degeneration. Curr. Opin. Ophthalmol. 2015, 26, 188-193. [CrossRef] [PubMed]

74. Binley, K.; Widdowson, P.S.; Kelleher, M.; de Belin, J.; Loader, J.; Ferrige, G.; Carlucci, M.; Esapa, M.; Chipchase, D.; Angell-Manning, D.; et al. Safety and biodistribution of an equine infectious anemia virus-based gene therapy, retinostat(®), for age-related macular degeneration. Hum. Gene Ther. 2012, 23, 980-991. [CrossRef] [PubMed]

75. Campochiaro, P.A.; Lauer, A.K.; Sohn, E.H.; Mir, T.A.; Naylor, S.; Anderton, M.C.; Kelleher, M.; Harrop, R.; Ellis, S.; Mitrophanous, K.A. Lentiviral vector gene transfer of endostatin/angiostatin for macular degeneration (GEM) study. Hum. Gene Ther. 2016, 28, 99-111. [CrossRef] [PubMed]

76. Daya, S.; Berns, K.I. Gene therapy using adeno-associated virus vectors. Clin. Microbiol. Rev. 2008, 21, 583-593. [CrossRef] [PubMed]

77. Solinis, M.A.; del Pozo-Rodriguez, A.; Apaolaza, P.S.; Rodriguez-Gascon, A. Treatment of ocular disorders by gene therapy. Eur. J. Pharm. Biopharm. 2015, 95, 331-342. [CrossRef] [PubMed]

78. Liu, M.M.; Tuo, J.; Chan, C.C. Republished review: Gene therapy for ocular diseases. Postgrad. Med. J. 2011, 87, 487-495. [CrossRef] [PubMed] 
79. Sarra, G.M.; Stephens, C.; Schlichtenbrede, F.C.; Bainbridge, J.W.; Thrasher, A.J.; Luthert, P.J.; Ali, R.R. Kinetics of transgene expression in mouse retina following sub-retinal injection of recombinant adeno-associated virus. Vis. Res. 2002, 42, 541-549. [CrossRef]

80. Garoon, R.B.; Stout, J.T. Update on ocular gene therapy and advances in treatment of inherited retinal diseases and exudative macular degeneration. Curr. Opin. Ophthalmol. 2016, 27, 268-273. [CrossRef] [PubMed]

81. Hirsch, M.L.; Wolf, S.J.; Samulski, R.J. Delivering transgenic DNA exceeding the carrying capacity of AAV vectors. Methods Mol. Biol. 2016, 1382, 21-39. [PubMed]

82. Yan, Z.; Zhang, Y.; Duan, D.; Engelhardt, J.F. Trans-splicing vectors expand the utility of adeno-associated virus for gene therapy. Proc. Natl. Acad. Sci. USA 2000, 97, 6716-6721. [CrossRef] [PubMed]

83. Reich, S.J.; Auricchio, A.; Hildinger, M.; Glover, E.; Maguire, A.M.; Wilson, J.M.; Bennett, J. Efficient trans-splicing in the retina expands the utility of adeno-associated virus as a vector for gene therapy. Hum. Gene Ther. 2003, 14, 37-44. [CrossRef] [PubMed]

84. Dyka, F.M.; Boye, S.L.; Chiodo, V.A.; Hauswirth, W.W.; Boye, S.E. Dual adeno-associated virus vectors result in efficient in vitro and in vivo expression of an oversized gene, MYO7A. Hum. Gene Ther. Methods 2014, 25, 166-177. [CrossRef] [PubMed]

85. Trapani, I.; Colella, P.; Sommella, A.; Iodice, C.; Cesi, G.; de Simone, S.; Marrocco, E.; Rossi, S.; Giunti, M.; Palfi, A.; et al. Effective delivery of large genes to the retina by dual AAV vectors. EMBO Mol. Med. 2014, 6, 194-211. [CrossRef] [PubMed]

86. Semple-Rowland, S.L.; Berry, J. Use of lentiviral vectors to deliver and express bicistronic transgenes in developing chicken embryos. Methods 2014, 66, 466-473. [CrossRef] [PubMed]

87. Cepko, C.L.; Vandenberghe, L.H. Retinal gene therapy coming of age. Hum. Gene Ther. 2013, $24,242-244$. [CrossRef] [PubMed]

88. Jacobson, S.G.; Cideciyan, A.V.; Peshenko, I.V.; Sumaroka, A.; Olshevskaya, E.V.; Cao, L.; Schwartz, S.B.; Roman, A.J.; Olivares, M.B.; Sadigh, S.; et al. Determining consequences of retinal membrane guanylyl cyclase (RetGC1) deficiency in human Leber congenital amaurosis en route to therapy: Residual cone-photoreceptor vision correlates with biochemical properties of the mutants. Hum. Mol. Genet. 2013, 22, 168-183. [CrossRef] [PubMed]

89. Provost, N.; Le Meur, G.; Weber, M.; Mendes-Madeira, A.; Podevin, G.; Cherel, Y.; Colle, M.A.; Deschamps, J.Y.; Moullier, P.; Rolling, F. Biodistribution of rAAV vectors following intraocular administration: Evidence for the presence and persistence of vector DNA in the optic nerve and in the brain. Mol. Ther. 2005, 11, 275-283. [CrossRef] [PubMed]

90. Yin, L.; Greenberg, K.; Hunter, J.J.; Dalkara, D.; Kolstad, K.D.; Masella, B.D.; Wolfe, R.; Visel, M.; Stone, D.; Libby, R.T.; et al. Intravitreal injection of AAV2 transduces macaque inner retina. Investig. Ophthalmol. Vis. Sci. 2011, 52, 2775-2783. [CrossRef] [PubMed]

91. Bennett, J.; Maguire, A.M.; Cideciyan, A.V.; Schnell, M.; Glover, E.; Anand, V.; Aleman, T.S.; Chirmule, N.; Gupta, A.R.; Huang, Y.; et al. Stable transgene expression in rod photoreceptors after recombinant adeno-associated virus-mediated gene transfer to monkey retina. Proc. Natl. Acad. Sci. USA 1999, 96, 9920-9925. [CrossRef] [PubMed]

92. Yu-Wai-Man, P. Genetic manipulation for inherited neurodegenerative diseases: Myth or reality? Br. J. Ophthalmol. 2016, 100, 1322-1331. [CrossRef] [PubMed]

93. Park, T.K.; Wu, Z.; Kjellstrom, S.; Zeng, Y.; Bush, R.A.; Sieving, P.A.; Colosi, P. Intravitreal delivery of AAV8 retinoschisin results in cell type-specific gene expression and retinal rescue in the RS1-KO mouse. Gene Ther. 2009, 16, 916-926. [CrossRef] [PubMed]

94. Byrne, L.C.; Ozturk, B.E.; Lee, T.; Fortuny, C.; Visel, M.; Dalkara, D.; Schaffer, D.V.; Flannery, J.G. Retinoschisin gene therapy in photoreceptors, muller glia or all retinal cells in the RS1h-/- mouse. Gene Ther. 2014, 21, 585-592. [CrossRef] [PubMed]

95. Bennett, J. Immune response following intraocular delivery of recombinant viral vectors. Gene Ther. 2003, 10, 977-982. [CrossRef] [PubMed]

96. Li, Q.; Miller, R.; Han, P.Y.; Pang, J.; Dinculescu, A.; Chiodo, V.; Hauswirth, W.W. Intraocular route of AAV2 vector administration defines humoral immune response and therapeutic potential. Mol. Vis. 2008, 14, 1760-1769. [PubMed] 
97. Matsuda, T.; Cepko, C.L. Electroporation and rna interference in the rodent retina in vivo and in vitro. Proc. Natl. Acad. Sci. USA 2004, 101, 16-22. [CrossRef] [PubMed]

98. Koirala, A.; Conley, S.M.; Naash, M.I. A review of therapeutic prospects of non-viral gene therapy in the retinal pigment epithelium. Biomaterials 2013, 34, 7158-7167. [CrossRef] [PubMed]

99. Touchard, E.; Berdugo, M.; Bigey, P.; El Sanharawi, M.; Savoldelli, M.; Naud, M.C.; Jeanny, J.C.; Behar-Cohen, F. Suprachoroidal electrotransfer: A nonviral gene delivery method to transfect the choroid and the retina without detaching the retina. Mol. Ther. 2012, 20, 1559-1570. [CrossRef] [PubMed]

100. Adijanto, J.; Naash, M.I. Nanoparticle-based technologies for retinal gene therapy. Eur. J. Pharm. Biopharm. 2015, 95, 353-367. [CrossRef] [PubMed]

101. Han, Z.; Conley, S.M.; Naash, M.I. Aav and compacted DNA nanoparticles for the treatment of retinal disorders: Challenges and future prospects. Investig. Ophthalmol. Vis. Sci. 2011, 52, 3051-3059. [CrossRef] [PubMed]

102. Han, Z.; Conley, S.M.; Makkia, R.; Guo, J.; Cooper, M.J.; Naash, M.I. Comparative analysis of DNA nanoparticles and AAVs for ocular gene delivery. PLoS ONE 2012, 7, e52189. [CrossRef] [PubMed]

103. Tamboli, V.; Mishra, G.P.; Mitrat, A.K. Polymeric vectors for ocular gene delivery. Ther. Deliv. 2011, 2, $523-536$. [CrossRef] [PubMed]

104. Jin, J.; Zhou, K.K.; Park, K.; Hu, Y.; Xu, X.; Zheng, Z.; Tyagi, P.; Kompella, U.B.; Ma, J.X. Anti-inflammatory and antiangiogenic effects of nanoparticle-mediated delivery of a natural angiogenic inhibitor. Investig. Ophthalmol. Vis. Sci. 2011, 52, 6230-6237. [CrossRef] [PubMed]

105. Kachi, S.; Esumi, N.; Zack, D.J.; Campochiaro, P.A. Sustained expression after nonviral ocular gene transfer using mammalian promoters. Gene Ther. 2006, 13, 798-804. [CrossRef] [PubMed]

106. Kachi, S.; Oshima, Y.; Esumi, N.; Kachi, M.; Rogers, B.; Zack, D.J.; Campochiaro, P.A. Nonviral ocular gene transfer. Gene Ther. 2005, 12, 843-851. [CrossRef] [PubMed]

107. Liao, H.W.; Yau, K.W. In vivo gene delivery in the retina using polyethylenimine. Biotechniques 2007, 42, 285-286, 288. [CrossRef] [PubMed]

108. Marano, R.J.; Toth, I.; Wimmer, N.; Brankov, M.; Rakoczy, P.E. Dendrimer delivery of an anti-vegf oligonucleotide into the eye: A long-term study into inhibition of laser-induced CNV, distribution, uptake and toxicity. Gene Ther. 2005, 12, 1544-1550. [CrossRef] [PubMed]

109. Mitra, R.N.; Han, Z.; Merwin, M.; Al Taai, M.; Conley, S.M.; Naash, M.I. Synthesis and characterization of glycol chitosan DNA nanoparticles for retinal gene delivery. ChemMedChem 2014, 9, 189-196. [CrossRef] [PubMed]

110. Mo, Y.; Barnett, M.E.; Takemoto, D.; Davidson, H.; Kompella, U.B. Human serum albumin nanoparticles for efficient delivery of $\mathrm{Cu}, \mathrm{Zn}$ superoxide dismutase gene. Mol. Vis. 2007, 13, 746-757. [PubMed]

111. Park, K.; Chen, Y.; Hu, Y.; Mayo, A.S.; Kompella, U.B.; Longeras, R.; Ma, J.X. Nanoparticle-mediated expression of an angiogenic inhibitor ameliorates ischemia-induced retinal neovascularization and diabetes-induced retinal vascular leakage. Diabetes 2009, 58, 1902-1913. [CrossRef] [PubMed]

112. Zhang, C.; Wang, Y.S.; Wu, H.; Zhang, Z.X.; Cai, Y.; Hou, H.Y.; Zhao, W.; Yang, X.M.; Ma, J.X. Inhibitory efficacy of hypoxia-inducible factor $1 \alpha$ short hairpin RNA plasmid DNA-loaded poly (D, L-lactide-co-glycolide) nanoparticles on choroidal neovascularization in a laser-induced rat model. Gene Ther. 2010, 17, 338-351. [CrossRef] [PubMed]

113. Weleber, R.G.; Francis, P.J.; Trzupek, K.M.; Beattie, C. Leber congenital amaurosis. In GeneReviews ${ }^{\circledR}$; Pagon, R.A., Adam, M.P., Ardinger, H.H., Wallace, S.E., Amemiya, A., Bean, L.J.H., Bird, T.D., Fong, C.T., Mefford, H.C., Smith, R.J.H., et al., Eds.; University of Washington: Seattle, WA, USA, 1993-2017 (last update on 2 May 2013).

114. Redmond, T.M. Focus on molecules: RPE65, the visual cycle retinol isomerase. Exp. Eye Res. 2009, 88, 846-847. [CrossRef] [PubMed]

115. Koenekoop, R.K. An overview of leber congenital amaurosis: A model to understand human retinal development. Surv. Ophthalmol. 2004, 49, 379-398. [CrossRef] [PubMed]

116. Banin, E.; Bandah-Rozenfeld, D.; Obolensky, A.; Cideciyan, A.V.; Aleman, T.S.; Marks-Ohana, D.; Sela, M.; Boye, S.; Sumaroka, A.; Roman, A.J.; et al. Molecular anthropology meets genetic medicine to treat blindness in the North African Jewish population: Human gene therapy initiated in Israel. Hum. Gene Ther. 2010, 21, 1749-1757. [CrossRef] [PubMed] 
117. Cideciyan, A.V.; Aleman, T.S.; Boye, S.L.; Schwartz, S.B.; Kaushal, S.; Roman, A.J.; Pang, J.J.; Sumaroka, A.; Windsor, E.A.; Wilson, J.M.; et al. Human gene therapy for RPE65 isomerase deficiency activates the retinoid cycle of vision but with slow rod kinetics. Proc. Natl. Acad. Sci. USA 2008, 105, 15112-15117. [CrossRef] [PubMed]

118. Cideciyan, A.V.; Hauswirth, W.W.; Aleman, T.S.; Kaushal, S.; Schwartz, S.B.; Boye, S.L.; Windsor, E.A.; Conlon, T.J.; Sumaroka, A.; Pang, J.J.; et al. Human RPE65 gene therapy for leber congenital amaurosis: Persistence of early visual improvements and safety at 1 year. Hum. Gene Ther. 2009, 20, 999-1004. [CrossRef] [PubMed]

119. Testa, F.; Maguire, A.M.; Rossi, S.; Pierce, E.A.; Melillo, P.; Marshall, K.; Banfi, S.; Surace, E.M.; Sun, J.; Acerra, C.; et al. Three-year follow-up after unilateral subretinal delivery of adeno-associated virus in patients with Leber congenital amaurosis type 2. Ophthalmology 2013, 120, 1283-1291. [CrossRef] [PubMed]

120. MacDonald, I.M.; Hume, S.; Chan, S.; Seabra, M.C. Choroideremia. In GeneReviews@; Pagon, R.A., Adam, M.P., Ardinger, H.H., Wallace, S.E., Amemiya, A., Bean, L.J.H., Bird, T.D., Fong, C.T., Mefford, H.C., Smith, R.J.H., et al., Eds.; University of Washington: Seattle, WA, USA, 1993-2017; (last update on 26 February 2015).

121. Zinkernagel, M.S.; MacLaren, R.E. Recent advances and future prospects in choroideremia. Clin. Ophthalmol. 2015, 9, 2195-2200. [CrossRef] [PubMed]

122. Ma, K.K.; Lin, J.; Boudreault, K.; Chen, R.W.; Tsang, S.H. Phenotyping choroideremia and its carrier state with multimodal imaging techniques. Retin. Cases Brief Rep. 2017, 11, S178-S181. [CrossRef] [PubMed]

123. Edwards, T.L.; Jolly, J.K.; Groppe, M.; Barnard, A.R.; Cottriall, C.L.; Tolmachova, T.; Black, G.C.; Webster, A.R.; Lotery, A.J.; Holder, G.E.; et al. Visual acuity after retinal gene therapy for choroideremia. N. Engl. J. Med. 2016, 374, 1996-1998. [CrossRef] [PubMed]

124. Barnard, A.R.; Groppe, M.; MacLaren, R.E. Gene therapy for choroideremia using an adeno-associated viral (AAV) vector. Cold Spring Harb. Perspect. Med. 2014, 5, a017293. [CrossRef] [PubMed]

125. Johnson, S.; Michaelides, M.; Aligianis, I.A.; Ainsworth, J.R.; Mollon, J.D.; Maher, E.R.; Moore, A.T.; Hunt, D.M. Achromatopsia caused by novel mutations in both CNGA3 and CNGB3. J. Med. Genet. 2004, 41, e20. [CrossRef] [PubMed]

126. Greenberg, J.P.; Sherman, J.; Zweifel, S.A.; Chen, R.W.; Duncker, T.; Kohl, S.; Baumann, B.; Wissinger, B.; Yannuzzi, L.A.; Tsang, S.H. Spectral-domain optical coherence tomography staging and autofluorescence imaging in achromatopsia. JAMA Ophthalmol. 2014, 132, 437-445. [CrossRef] [PubMed]

127. Kohl, S.; Varsanyi, B.; Antunes, G.A.; Baumann, B.; Hoyng, C.B.; Jagle, H.; Rosenberg, T.; Kellner, U.; Lorenz, B.; Salati, R.; et al. CNGB3 mutations account for $50 \%$ of all cases with autosomal recessive achromatopsia. Eur. J. Hum. Genet. 2005, 13, 302-308. [CrossRef] [PubMed]

128. Giblin, J.P.; Comes, N.; Strauss, O.; Gasull, X. Ion channels in the eye: Involvement in ocular pathologies. Adv. Protein Chem. Struct. Biol. 2016, 104, 157-231. [PubMed]

129. Mooy, C.M.; Van Den Born, L.I.; Baarsma, S.; Paridaens, D.A.; Kraaijenbrink, T.; Bergen, A.; Weber, B.H. Hereditary X-linked juvenile retinoschisis: A review of the role of Müller cells. Arch. Ophthalmol. 2002, 120, 979-984. [PubMed]

130. Molday, R.S.; Kellner, U.; Weber, B.H. X-linked juvenile retinoschisis: Clinical diagnosis, genetic analysis, and molecular mechanisms. Prog. Retin. Eye Res. 2012, 31, 195-212. [CrossRef] [PubMed]

131. Yu-Wai-Man, P.; Chinnery, P.F. Leber hereditary optic neuropathy. In GeneReviews ${ }^{\circ} ;$ Pagon, R.A., Adam, M.P., Ardinger, H.H., Wallace, S.E., Amemiya, A., Bean, L.J.H., Bird, T.D., Fong, C.T., Mefford, H.C., Smith, R.J.H., et al., Eds.; University of Washington: Seattle, WA, USA, 1993-2017 (last update on 23 June 2016).

132. Qi, X.; Sun, L.; Lewin, A.S.; Hauswirth, W.W.; Guy, J. The mutant human ND4 subunit of complex I induces optic neuropathy in the mouse. Investig. Ophthalmol. Vis. Sci. 2007, 48, 1-10. [CrossRef] [PubMed]

133. Ellouze, S.; Augustin, S.; Bouaita, A.; Bonnet, C.; Simonutti, M.; Forster, V.; Picaud, S.; Sahel, J.A.; Corral-Debrinski, M. Optimized allotopic expression of the human mitochondrial ND4 prevents blindness in a rat model of mitochondrial dysfunction. Am. J. Hum. Genet. 2008, 83, 373-387. [CrossRef] [PubMed]

134. Guy, J.; Qi, X.; Koilkonda, R.D.; Arguello, T.; Chou, T.H.; Ruggeri, M.; Porciatti, V.; Lewin, A.S.; Hauswirth, W.W. Efficiency and safety of AAV-mediated gene delivery of the human ND4 complex I subunit in the mouse visual system. Investig. Ophthalmol. Vis. Sci. 2009, 50, 4205-4214. [CrossRef] [PubMed] 
135. Zhang, Q. Retinitis pigmentosa: Progress and perspective. Asia Pac. J. Ophthalmol. 2016, 5, $265-271$. [CrossRef] [PubMed]

136. Hamel, C. Retinitis pigmentosa. Orphanet J. Rare Dis. 2006, 1, 40. [CrossRef] [PubMed]

137. Sadeghi, A.M.; Eriksson, K.; Kimberling, W.J.; Sjostrom, A.; Moller, C. Longterm visual prognosis in usher syndrome types 1 and 2. Acta Ophthalmol. Scand. 2006, 84, 537-544. [CrossRef] [PubMed]

138. Kimberling, W.J.; Hildebrand, M.S.; Shearer, A.E.; Jensen, M.L.; Halder, J.A.; Trzupek, K.; Cohn, E.S.; Weleber, R.G.; Stone, E.M.; Smith, R.J. Frequency of usher syndrome in two pediatric populations: Implications for genetic screening of deaf and hard of hearing children. Genet. Med. 2010, 12, 512-516. [CrossRef] [PubMed]

139. Williams, D.S.; Lopes, V.S. The many different cellular functions of MYO7A in the retina. Biochem. Soc. Trans. 2011, 39, 1207-1210. [CrossRef] [PubMed]

140. Charbel Issa, P.; Barnard, A.R.; Herrmann, P.; Washington, I.; MacLaren, R.E. Rescue of the Stargardt phenotype in $A B C A 4$ knockout mice through inhibition of vitamin A dimerization. Proc. Natl. Acad. Sci. USA 2015, 112, 8415-8420. [CrossRef] [PubMed]

141. Congdon, N.; O'Colmain, B.; Klaver, C.C.; Klein, R.; Munoz, B.; Friedman, D.S.; Kempen, J.; Taylor, H.R.; Mitchell, P.; Eye Diseases Prevalence Research, G. Causes and prevalence of visual impairment among adults in the United States. Arch. Ophthalmol. 2004, 122, 477-485. [PubMed]

142. Alexandru, M.R.; Alexandra, N.M. Wet age related macular degeneration management and follow-up. Rom. J. Ophthalmol. 2016, 60, 9-13. [PubMed]

143. Barrangou, R.; Fremaux, C.; Deveau, H.; Richards, M.; Boyaval, P.; Moineau, S.; Romero, D.A.; Horvath, P. CRISPR provides acquired resistance against viruses in prokaryotes. Science 2007, 315, 1709-1712. [CrossRef] [PubMed]

144. Makarova, K.S.; Aravind, L.; Grishin, N.V.; Rogozin, I.B.; Koonin, E.V. A DNA repair system specific for thermophilic archaea and bacteria predicted by genomic context analysis. Nucleic Acids Res. 2002, 30, 482-496. [CrossRef] [PubMed]

145. Mojica, F.J.; Diez-Villasenor, C.; Soria, E.; Juez, G. Biological significance of a family of regularly spaced repeats in the genomes of archaea, bacteria and mitochondria. Mol. Microbiol. 2000, 36, 244-246. [CrossRef] [PubMed]

146. Wiedenheft, B.; Zhou, K.; Jinek, M.; Coyle, S.M.; Ma, W.; Doudna, J.A. Structural basis for DNase activity of a conserved protein implicated in CRISPR-mediated genome defense. Structure 2009, 17, 904-912. [CrossRef] [PubMed]

147. Wiedenheft, B.; Sternberg, S.H.; Doudna, J.A. RNA-guided genetic silencing systems in bacteria and archaea. Nature 2012, 482, 331-338. [CrossRef] [PubMed]

148. Jinek, M.; Chylinski, K.; Fonfara, I.; Hauer, M.; Doudna, J.A.; Charpentier, E. A programmable dual-RNA-guided DNA endonuclease in adaptive bacterial immunity. Science 2012, 337, 816-821. [CrossRef] [PubMed]

149. Pardo, B.; Gomez-Gonzalez, B.; Aguilera, A. DNA repair in mammalian cells: DNA double-strand break repair: How to fix a broken relationship. Cell Mol. Life Sci. 2009, 66, 1039-1056. [CrossRef] [PubMed]

150. Oude Blenke, E.; Evers, M.J.; Mastrobattista, E.; van der Oost, J. CRISPR-Cas9 gene editing: Delivery aspects and therapeutic potential. J. Control. Release 2016, 244, 139-148. [CrossRef] [PubMed]

151. Chu, V.T.; Weber, T.; Wefers, B.; Wurst, W.; Sander, S.; Rajewsky, K.; Kuhn, R. Increasing the efficiency of homology-directed repair for CRISPR-Cas9-induced precise gene editing in mammalian cells. Nat. Biotechnol. 2015, 33, 543-548. [CrossRef] [PubMed]

152. Dow, L.E. Modeling disease in vivo with CRISPR/Cas9. Trends Mol. Med. 2015, 21, 609-621. [CrossRef] [PubMed]

153. Bakondi, B.; Lv, W.; Lu, B.; Jones, M.K.; Tsai, Y.; Kim, K.J.; Levy, R.; Akhtar, A.A.; Breunig, J.J.; Svendsen, C.N.; et al. In vivo CRISPR/Cas9 gene editing corrects retinal dystrophy in the S334ter-3 rat model of autosomal dominant retinitis pigmentosa. Mol. Ther. 2016, 24, 556-563. [CrossRef] [PubMed]

154. Wu, W.H.; Tsai, Y.T.; Justus, S.; Lee, T.T.; Zhang, L.; Lin, C.S.; Bassuk, A.G.; Mahajan, V.B.; Tsang, S.H. CRISPR repair reveals causative mutation in a preclinical model of retinitis pigmentosa. Mol. Ther. 2016, 24, 1388-1394. [CrossRef] [PubMed]

155. Zhong, H.; Chen, Y.; Li, Y.; Chen, R.; Mardon, G. CRISPR-engineered mosaicism rapidly reveals that loss of Kcnj13 function in mice mimics human disease phenotypes. Sci. Rep. 2015, 5, 8366. [CrossRef] [PubMed] 
156. Ota, S.; Hisano, Y.; Ikawa, Y.; Kawahara, A. Multiple genome modifications by the CRISPR/Cas9 system in zebrafish. Genes Cells 2014, 19, 555-564. [CrossRef] [PubMed]

157. Shah, A.N.; Davey, C.F.; Whitebirch, A.C.; Miller, A.C.; Moens, C.B. Rapid reverse genetic screening using CRISPR in zebrafish. Nat. Methods 2015, 12, 535-540. [CrossRef] [PubMed]

158. Wang, S.; Sengel, C.; Emerson, M.M.; Cepko, C.L. A gene regulatory network controls the binary fate decision of rod and bipolar cells in the vertebrate retina. Dev. Cell 2014, 30, 513-527. [CrossRef] [PubMed]

159. Cho, S.W.; Kim, S.; Kim, J.M.; Kim, J.S. Targeted genome engineering in human cells with the Cas9 RNA-guided endonuclease. Nat. Biotechnol. 2013, 31, 230-232. [CrossRef] [PubMed]

160. Cong, L.; Ran, F.A.; Cox, D.; Lin, S.; Barretto, R.; Habib, N.; Hsu, P.D.; Wu, X.; Jiang, W.; Marraffini, L.A.; et al. Multiplex genome engineering using CRISPR/Cas systems. Science 2013, 339, 819-823. [CrossRef] [PubMed]

161. Jinek, M.; East, A.; Cheng, A.; Lin, S.; Ma, E.; Doudna, J. RNA-programmed genome editing in human cells. eLife 2013, 2, e00471. [CrossRef] [PubMed]

162. Mali, P.; Yang, L.; Esvelt, K.M.; Aach, J.; Guell, M.; DiCarlo, J.E.; Norville, J.E.; Church, G.M. RNA-guided human genome engineering via Cas9. Science 2013, 339, 823-826. [CrossRef] [PubMed]

163. Bassuk, A.G.; Zheng, A.; Li, Y.; Tsang, S.H.; Mahajan, V.B. Precision medicine: Genetic repair of retinitis pigmentosa in patient-derived stem cells. Sci. Rep. 2016, 6, 19969. [CrossRef] [PubMed]

164. Hung, S.S.; Chrysostomou, V.; Li, F.; Lim, J.K.; Wang, J.H.; Powell, J.E.; Tu, L.; Daniszewski, M.; Lo, C.; Wong, R.C.; et al. AAV-mediated CRISPR/Cas gene editing of retinal cells in vivo. Investig. Ophthalmol. Vis. Sci. 2016, 57, 3470-3476. [CrossRef] [PubMed]

165. Fu, Y.; Sander, J.D.; Reyon, D.; Cascio, V.M.; Joung, J.K. Improving CRISPR-Cas nuclease specificity using truncated guide RNAs. Nat. Biotechnol. 2014, 32, 279-284. [CrossRef] [PubMed]

166. Mali, P.; Aach, J.; Stranges, P.B.; Esvelt, K.M.; Moosburner, M.; Kosuri, S.; Yang, L.; Church, G.M. Cas9 transcriptional activators for target specificity screening and paired nickases for cooperative genome engineering. Nat. Biotechnol. 2013, 31, 833-838. [CrossRef] [PubMed]

167. Shen, B.; Zhang, W.; Zhang, J.; Zhou, J.; Wang, J.; Chen, L.; Wang, L.; Hodgkins, A.; Iyer, V.; Huang, X.; et al. Efficient genome modification by CRISPR-Cas9 nickase with minimal off-target effects. Nat. Methods 2014, 11, 399-402. [CrossRef] [PubMed]

168. Ran, F.A.; Hsu, P.D.; Lin, C.Y.; Gootenberg, J.S.; Konermann, S.; Trevino, A.E.; Scott, D.A.; Inoue, A.; Matoba, S.; Zhang, Y.; et al. Double nicking by RNA-guided CRISPR Cas9 for enhanced genome editing specificity. Cell 2013, 154, 1380-1389. [CrossRef] [PubMed]

169. Hsu, P.D.; Scott, D.A.; Weinstein, J.A.; Ran, F.A.; Konermann, S.; Agarwala, V.; Li, Y.; Fine, E.J.; Wu, X.; Shalem, O.; et al. DNA targeting specificity of RNA-guided Cas9 nucleases. Nat. Biotechnol. 2013, 31, 827-832. [CrossRef] [PubMed]

170. Qi, L.S.; Larson, M.H.; Gilbert, L.A.; Doudna, J.A.; Weissman, J.S.; Arkin, A.P.; Lim, W.A. Repurposing CRISPR as an RNA-guided platform for sequence-specific control of gene expression. Cell 2013, 152, 1173-1183. [CrossRef] [PubMed]

171. Bikard, D.; Jiang, W.; Samai, P.; Hochschild, A.; Zhang, F.; Marraffini, L.A. Programmable repression and activation of bacterial gene expression using an engineered CRISPR-Cas system. Nucleic Acids Res. 2013, 41, 7429-7437. [CrossRef] [PubMed]

172. Gilbert, L.A.; Horlbeck, M.A.; Adamson, B.; Villalta, J.E.; Chen, Y.; Whitehead, E.H.; Guimaraes, C.; Panning, B.; Ploegh, H.L.; Bassik, M.C.; et al. Genome-scale CRISPR-mediated control of gene repression and activation. Cell 2014, 159, 647-661. [CrossRef] [PubMed]

173. Gilbert, L.A.; Larson, M.H.; Morsut, L.; Liu, Z.; Brar, G.A.; Torres, S.E.; Stern-Ginossar, N.; Brandman, O.; Whitehead, E.H.; Doudna, J.A.; et al. CRISPR-mediated modular RNA-guided regulation of transcription in eukaryotes. Cell 2013, 154, 442-451. [CrossRef] [PubMed]

174. Cheng, A.W.; Wang, H.; Yang, H.; Shi, L.; Katz, Y.; Theunissen, T.W.; Rangarajan, S.; Shivalila, C.S.; Dadon, D.B.; Jaenisch, R. Multiplexed activation of endogenous genes by CRISPR-on, an RNA-guided transcriptional activator system. Cell Res. 2013, 23, 1163-1171. [CrossRef] [PubMed]

175. Jung, C.J.; Menoret, S.; Brusselle, L.; Tesson, L.; Usal, C.; Chenouard, V.; Remy, S.; Ouisse, L.H.; Poirier, N.; Vanhove, B.; et al. Comparative analysis of piggyBac, CRISPR/Cas9 and TALEN mediated BAC transgenesis in the zygote for the generation of humanized SIRPA rats. Sci. Rep. 2016, 6, 31455. [CrossRef] [PubMed]

176. Maeder, M.L.; Linder, S.J.; Cascio, V.M.; Fu, Y.; Ho, Q.H.; Joung, J.K. CRISPR RNA-guided activation of endogenous human genes. Nat. Methods 2013, 10, 977-979. [CrossRef] [PubMed] 
177. Perez-Pinera, P.; Ousterout, D.G.; Brunger, J.M.; Farin, A.M.; Glass, K.A.; Guilak, F.; Crawford, G.E.; Hartemink, A.J.; Gersbach, C.A. Synergistic and tunable human gene activation by combinations of synthetic transcription factors. Nat. Methods 2013, 10, 239-242. [CrossRef] [PubMed]

178. Xiong, X.; Chen, M.; Lim, W.A.; Zhao, D.; Qi, L.S. CRISPR/Cas9 for human genome engineering and disease research. Annu. Rev. Genom. Hum. Genet. 2016, 17, 131-154. [CrossRef] [PubMed]

179. Komor, A.C.; Kim, Y.B.; Packer, M.S.; Zuris, J.A.; Liu, D.R. Programmable editing of a target base in genomic DNA without double-stranded DNA cleavage. Nature 2016, 533, 420-424. [CrossRef] [PubMed]

180. Hess, G.T.; Fresard, L.; Han, K.; Lee, C.H.; Li, A.; Cimprich, K.A.; Montgomery, S.B.; Bassik, M.C. Directed evolution using dCas9-targeted somatic hypermutation in mammalian cells. Nat. Methods 2016, 13, 1036-1042. [CrossRef] [PubMed]

(C) 2017 by the authors; licensee MDPI, Basel, Switzerland. This article is an open access article distributed under the terms and conditions of the Creative Commons Attribution (CC BY) license (http:/ / creativecommons.org/licenses/by/4.0/). 